
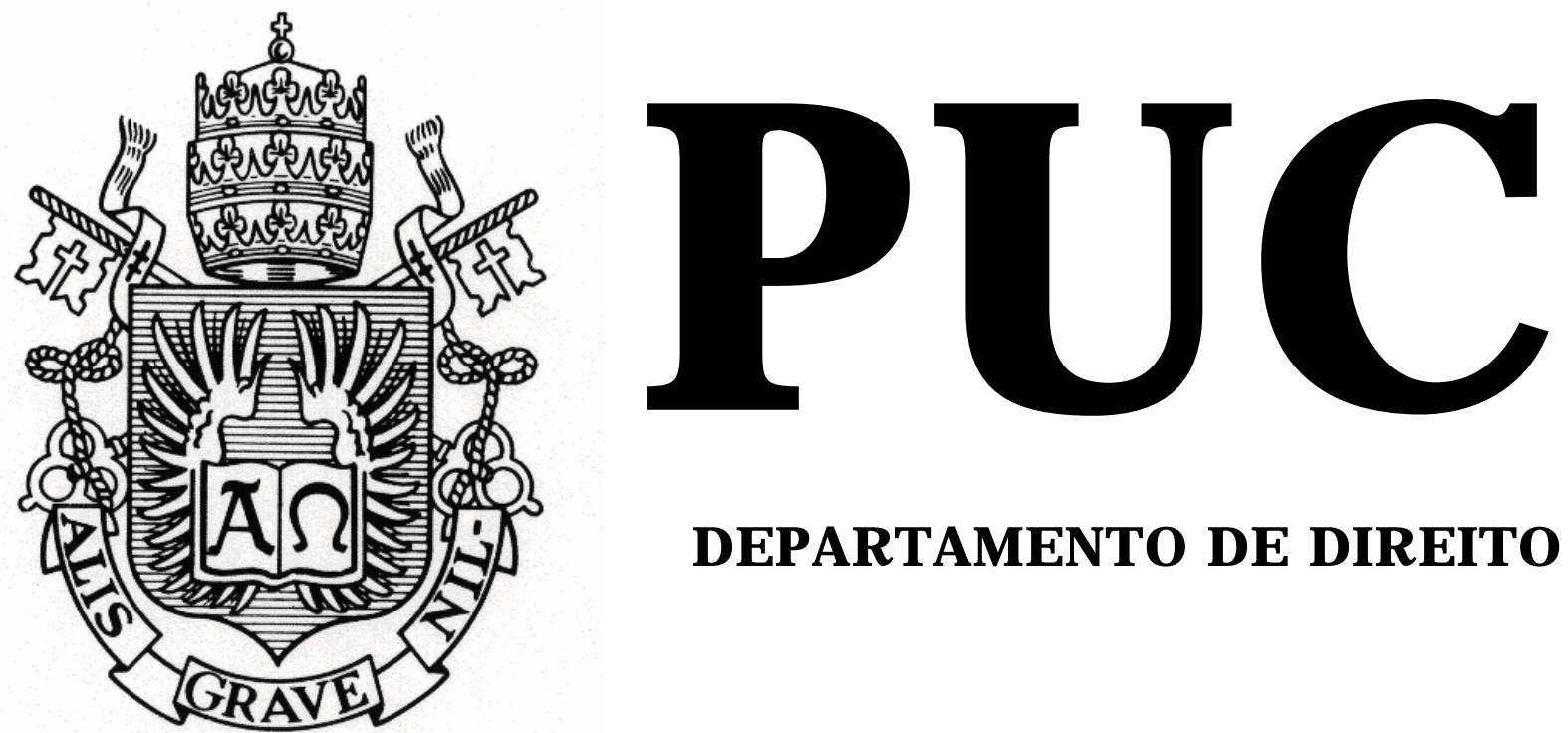

DEPARTAMENTO DE DIREITO

\title{
OS PADRÕES ESTABELECIDOS PELA CORTE INTERAMERICANA DE DIREITOS HUMANOS SOBRE LIBERDADE DE EXPRESSÃO E A ANÁLISE DO CASO RÍOS E OUTROS VS. VENEZUELA
}

por

ANDREA BANDEIRA DE MELLO SCHETTINI

ORIENTADOR(A): Márcia Nina Bernardes

2010.1

PONTIFÍCIA UNIVERSIDADE CATÓLICA DO RIO DE JANEIRO

RUA MARQUÊS DE SÃO VICENTE, 225 - CEP 22453-900

RIO DE JANEIRO - BRASIL 


\title{
OS PADRÕES ESTABELECIDOS PELA CORTE
} INTERAMERICANA DE DIREITOS HUMANOS SOBRE LIBERDADE DE EXPRESSÃO E A ANÁlISE DO CASO RÍOS E OUTROS VS. VENEZUELA

\author{
por \\ Andrea Bandeira de Mello Schettini
}

Monografia presentada ao Departamento de Direito da Pontifícia Universidade Católica do Rio de Janeiro (PUC-Rio) para a obtenção do Título de Bacharel em Direito.

Orientador(a): Márcia Nina Bernardes 


\section{Agradecimentos}

À toda minha família, por tudo que aprendi até hoje.

À minha mãe, por todo o seu esforço, carinho e amor incondicional e por ter me ensinado a acreditar em todos os meus sonhos.

À minha avó, Stella, pelo exemplo e ensinamentos de sempre.

Ao meu irmão, Beto, pelo amor e tolerância de todos os dias.

À minha orientadora, Márcia Nina, pela excelente e atenciosa orientação.

Às minhas amigas, pelos momentos de alegria e reflexão.

À Lele e Pilar, pelo aprendizado através da convivência e do carinho.

À PUC-Rio por ter me proporcionado a possibilidade de participar da Competição de Julgamento Simulado do Sistema Interamericano de Direitos Humanos em Washington, experiência extremamente gratificante e desafiadora, que me permitiu conhecer e desenvolver meu estudo acerca do direito à liberdade de expressão, tema desse trabalho.

Aos alunos e professores do grupo "Simulações e Realidades", Fábio, Gabriel, Tereza, Luiza, Maria, Carolina Campos Melo, Raquel Herdy e Daniela Vargas pelo conhecimento e pelas trocas que me permitiram conhecer os direitos humanos, acreditar em mudanças e tornaram a universidade mais prazerosa e interessante. 


\section{Resumo}

O tema do presente trabalho tem por objetivo realizar uma análise dos padrões estabelecidos pela Corte Interamericana de Direitos Humanos em sua jurisprudência em matéria de liberdade de expressão e os desafios impostos pelo Caso Ríos e outros vs. Venezuela para a implementação e aplicação de tais padrões. Inicialmente, é analisado o Sistema Interamericano de Proteção dos Direitos Humanos em seu conjunto, o âmbito normativo e os órgãos que atuam na proteção da liberdade de expressão. Em seguida, são expostos os padrões já estabelecidos pela Corte Interamericana de Direitos Humanos acerca do direito à liberdade de expressão, através de uma ampla análise de seus precedentes jurisprudenciais existentes até o momento. E, finalmente, é realizado um estudo aprofundado sobre o caso Ríos e outros vs. Venezuela, demonstrando os obstáculos, encontrados pela Corte Interamericana, para aplicação dos padrões já estabelecidos, diante da dificuldade de se identificar as restrições indiretas à liberdade de expressão, perpetuadas pelo Estado venezuelano, em razão de seu caráter político e da ausência de elementos probatórios contundentes e objetivos.

\section{Palavras- Chave}

Liberdade de expressão - Restrições indiretas à liberdade de expressão Sistema Interamericano de Proteção dos Direitos Humanos - Corte Interamericana de Direitos Humanos - Análise jurisprudencial - Caso Ríos e outros vs. Venezuela. 


\section{Sumário}

Introdução

\section{Capítulo 1 - O Sistema Interamericano de Proteção dos Direitos} Humanos e sua atuação na proteção da liberdade de expressão

1.1 Âmbito normativo do Sistema Interamericano na proteção da liberdade de expressão

1.2 Âmbito de atuação dos órgãos do Sistema Interamericano em matéria de liberdade de expressão

1.2.1Comissão Interamericana de Direitos Humanos

a) Relatoria Especial para Liberdade de Expressão

1.2.2 Corte Interamericana de Direitos Humanos
a) Competência contenciosa
b) Competência consultiva

Capítulo 2 - Os padrões estabelecidos pela jurisprudência da Corte Interamericana de Direitos Humanos em matéria de liberdade de expressão

2.1 A importância da Opinião Consultiva- OC 5 para a proteção da liberdade de expressão

2.2 Os elementos do direito à liberdade de expressão

2.3 Possibilidade de Restrições à liberdade de expressão

a) Proibição de censura prévia

b) Dos critérios para aplicação de responsabilidades ulteriores: Teste tripartide

b.1) Previsão Legal

b.2) Fins previstos no artigo 13.2

b.3) Necessidade em uma sociedade democrática

c) A proibição de restrições indiretas à liberdade de expressão 
Capítulo 3 - Os desafios impostos pelo Caso Ríos e outros vs. Venezuela

3.1 Fatos dos casos

3.2 O contexto histórico da Venezuela no momento dos fatos

3.3 Uma análise crítica da sentença da Corte Interamericana de Direitos Humanos

a) Questões políticas sensíveis

b) Elementos probatórios objetivos e contundentes

3.4 Especificidades do caso

Conclusão

Bibliografia 


\section{Lista de Abreviações}

Corte IDH Corte Interamericana de Direitos Humanos

Corte EDH Corte Européia de Direitos Humanos

CADH Convenção Americana de Direitos Humanos

CIDH Comissão Interamericana de Direitos Humanos

OEA Organização dos Estados Americanos

OC Opinião Consultiva 
"una sociedad que no está bien informada no es plenamente libre" (Corte IDH. OC-05 de 1985) 


\section{Introdução}

Após vivenciar mais de duas décadas marcadas por governos militares ditatoriais, a América Latina, no início dos anos 90, adentrou um período de transição de regimes autoritários para sistemas políticos democráticos ${ }^{1}$. Durante tal transição, práticas que até então eram freqüentes, como a supressão dos direitos civis, a censura prévia, a realização de eleições fraudulentas e ilegítimas, e a repressão a qualquer tipo de oposição ao governo tornaram-se incompatíveis com as demandas da democracia. A liberdade de expressão revelou-se imprescindível durante esse processo e tornou-se requisito sine qua non para a democracia ${ }^{2}$, consolidando-se como um direito fundamental e constitucionalmente protegido na ordem jurídica dos países latino-americanos.

Notadamente marcada por desigualdades sociais e alto índice de pobreza, na América Latina, a liberdade de expressão impõe-se como elemento democrático ainda mais relevante ${ }^{3}$. Um estudo do Banco Mundial concluiu que, historicamente, tem sido negado à população pobre latinoamericana um grau ativo de participação, o que lhes impossibilita atuar nas decisões que afetam suas vidas ${ }^{4}$. A exclusão de setores da população das decisões políticas dos países demonstra a instabilidade democrática existente na região. Conforme manifestado pela Relatoria Especial para a

\footnotetext{
${ }^{1}$ LEGLER, Thomas F.; LEAN, Sharon F.; BONIFACE, Dexter S. Promoting democracy in the Americas. $1^{\mathrm{a}}$ ed. Maryland: The Johns Hokins University Press, 2007. vii p.

2 BERTONI. Eduardo, A. La libertad de expresión em El Estado de derecho. Doctrina y jurisprudência nacional, extramjera e internacional. Prólogo de: Jonh Dingens. $2^{\mathrm{a}}$ ed. Buenos Aires: Del Puerto, 2007; IX p.

${ }^{3}$ CANTÓN, Santiago. La Relatoria Especial para La Libertad de Expresión de La Comisión Interamericana de Derechos Humanos. In: Instituto Americano de Derechos Humanos, Estúdios básicos de derechos humanos X. San José, Costa Rica: IIDH, 2000, 71p.

${ }^{4}$ Estudo mencionado: La voz de los pobres. Hay alguien que nos escuche? de Deepa Narayan, Banco Mundial, 2000. Disponível em: http://siteresources.worldbank.org/INTPOVERTY/Resources/335642-1124115102975/1555199_ $1124115187705 /$ vol1 sp.pdf. Acesso em: 03.05.10
} 
Liberdade de Expressão ${ }^{5}$ (doravante Relatoria ou Relatoria Especial) da Comissão Interamericana de Direitos Humanos (doravante Comissão ou Comissão Interamericana), 'o efetivo respeito à liberdade de expressão é uma ferramenta fundamental para incorporar a quem, por razões de pobreza, seja marginalizado tanto do acesso à informação, como de qualquer diálogo"6. E, nesse sentido, os protestos e manifestações sociais, na América Latina, representaram e ainda representam um importante instrumento de reivindicações perante os governos e, também, canais de denúncia pública sobre violações de direitos humanos ${ }^{7}$, o que demonstra a relevância da liberdade de expressão no contexto regional.

Embora seja possível notar importantes avanços normativos e práticos na proteção da liberdade de expressão no continente, não é possível afirmar que as ameaças e violações a esse direito cessaram no contexto atual. Obstáculos ao livre exercício da liberdade de expressão ainda existem e representam um desafio a ser enfrentado pelo Sistema Interamericano de Proteção dos Direitos Humanos (doravante Sistema Interamericano). Ainda são constantes as perseguições a jornalistas, que continuam a ser ameaçados, presos e, muitas vezes, perdem suas vidas em função da manifestação de opiniões. Conforme indicado pela Relatoria Especial para a Liberdade de Expressão, no mínimo treze jornalistas foram assassinados no ano de 2009 na região por razões relacionadas ao exercício de suas funções e foram apresentadas aproximadamente duzentas denúncias à Relatoria referentes a agressões, ameaças e intimidações contra comunicadores e os meios de comunicação ${ }^{8}$. Além disso, é freqüente o uso arbitrário e discriminatório da publicidade oficial por parte dos governos, a distribuição arbitrária das frequiências radioelétricas, a concentração da propriedade dos

\footnotetext{
${ }^{5}$ A Relatoria Especial para a Liberdade de Expressão é um órgão da Comissão Interamericana de Direitos Humanos criada em 1997, de caráter permanente, que atua dentro do marco jurídico da Comissão, mas com independência funcional e orçamento próprio.

${ }^{6}$ CIDH. Informe Anual de La Relatoria Especial para La Libertad de Expresión 2002, Capítulo IV, par. 7. (tradução prórpia)

${ }^{7}$ CIDH. Informe Anual de La Relatoria Especial para La Libertad de Expresión 2002, Capítulo IV, par. 29. (tradução prórpia)

${ }^{8}$ CIDH. Informe Anual de La Relatoria Especial para La Libertad de Expresión, 2009, Capítulo VII, par. 2.
} 
meios de comunicação e a criminalização das opiniões através de penas desproporcionais ${ }^{9}$.

Entretanto, o que revela maior importância para esse trabalho são as formas indiretas de violação à liberdade de expressão que, por se utilizarem de vias e meios indiretos, são menos visíveis e menos sujeitas de responsabilização, perpetuando-se, mais facilmente, no contexto latinoamericano atual, através de políticas públicas estatais que visam causar a intimidação e a autocensura, elementos que se mostram extremamente perigosos para o pleno exercício da liberdade de expressão, por revelarem uma grave e mascarada restrição a esse direito.

Nesse sentido, o objetivo desse trabalho será analisar a dificuldade enfrentada pelo Sistema Interamericano na proteção da liberdade de expressão no contexto atual do continente, através do estudo do caso Ríos e outros vs. Venezuela ${ }^{10}$, precedente recente e importante para a matéria. Embora não represente uma inovação nos padrões que a Corte Interamericana de Direitos Humanos (doravante Corte ou Corte Interamericana) vêm adotando em sua jurisprudência sobre liberdade de expressão, esse caso evidencia os desafios para a implementação dos padrões já consolidados e para a conseqüente responsabilização do Estado.

Para se chegar a essa conclusão, será feita uma análise crítica da sentença da Corte, que não foi capaz de responsabilizar o Estado venezuelano pela aplicação de restrições indiretas à liberdade de expressão e pelo exercício da autocensura. Isso se explica em decorrência dos obstáculos impostos por essas formas de restrição, evidenciados na demanda: a existência de questões políticas sensíveis envolvendo as restrições indiretas e o exercício da autocensura; e a ausência de elementos probatórios certos e objetivos que comprovassem o exercício de restrições indiretas à liberdade de expressão.

\footnotetext{
${ }^{9}$ ADC, Asociación por los derechos Civiles. A liberdade de expressão na jurisprudência da Corte Interamericana de direitos Humanos. Prólogo por Eduardo Bertoni. Pag. 9

${ }^{10}$ CORTE IDH. Rios e outros vs. Venezuela. Sentença 28 de janeiro de 2009.
} 
Importante destacar que, no contexto regional atual, a Venezuela é um dos países que mais chama atenção no que tange às constantes violações à liberdade de expressão ${ }^{11}$. A Relatoria Especial, em seu relatório sobre Democracia e Direitos Humanos na Venezuela, publicado no ano de 2009, apontou que não existem no país as condições necessárias para que os jornalistas exerçam suas funções livremente, sendo comum a utilização da força punitiva do Estado para intimidar e reprimir opiniões contrárias ao governo. Durante os anos de 2008 e 2009, foram registrados dois homicídios contra jornalistas e proprietários de meios de comunicação, além de agressões físicas e ameaças ${ }^{12}$. Nos últimos meses aumentaram os processos administrativos sancionatórios contra os meios de comunicação e foram, ainda, revogadas duzentas e quarenta licenças outorgadas a emissoras de rádio, assim como foram suspensas a transmissão de trinta e duas emissoras ${ }^{13}$, revelando um contexto de reiterada violação e supressão da liberdade de expressão em tal país.

Cabe ressaltar que o objetivo desse trabalho monográfico não é realizar um estudo sociológico ou político da Venezuela, mesmo que tais elementos possam aparecer eventualmente ao longo do texto, mas sim analisar os padrões estabelecidos pela jurisprudência da Corte Interamericana em matéria de liberdade de expressão e as dificuldades e os obstáculos enfrentados para a aplicação e implementação desses padrões, evidenciados pelo caso Ríos e outros vs. Venezuela, precedente jurisprudencial objeto de análise desse trabalho.

Sendo assim, o presente estudo dividir-se-á em três capítulos. O primeiro capítulo tratará do Sistema Interamericano de Proteção dos Direitos Humanos, seu âmbito normativo e a atuação dos órgãos do sistema na proteção da liberdade de expressão. O objetivo será analisar de forma

\footnotetext{
11 BERTONI. Eduardo A. La libertad de expresión em Venezuela. Disponível em www.anuariocdh.uchile.cl. Acesso em: 03.05.10

${ }^{12}$ CIDH. Democracia y Derechos Humanos em Venezuela. 2009. OEA/Ser.L/V/II. Doc. 54. Capítulo I, pag. X, par. 17.

${ }_{13}$ CIDH. Democracia y Derechos Humanos en Venezuela. 2009. OEA/Ser.L/V/II. Doc. 54. Capítulo I, pag. x, par. 20
} 
geral a atuação do Sistema Interamericano e de todos os seus órgãos na proteção a tal direito, a fim de demonstrar que esse é o sistema regional que apresenta mais garantias e maior proteção à liberdade de expressão.

O capítulo seguinte terá por objetivo traçar um panorama jurisprudencial em matéria de liberdade de expressão no Sistema Interamericano e, para tanto, analisará as decisões adotadas pela Corte Interamericana acerca da matéria até o presente momento. Essa análise é importante porque nos permite observar a existência de parâmetros consolidados sobre a proteção do direito à liberdade de expressão. Para o presente trabalho, será ressaltada a questão da proibição das restrições indiretas à liberdade de expressão que será criticamente abordada no terceiro capítulo.

E o terceiro e último capítulo tratará do estudo aprofundado do caso Ríos e outros vs. Venezuela, por meio da análise dos fatos da demanda, dos obstáculos impostos à Corte e de suas especificidades. Através desse caso, será desenvolvida uma análise crítica sobre a sentença da Corte, cabendo ser observada a dificuldade de se identificar e declarar a responsabilidade estatal pelo exercício de restrições indiretas à liberdade de expressão que ocasionaram a autocensura dos meios de comunicação e da sociedade em geral. Tal análise será baseada em dois obstáculos principais impostos pelas restrições indiretas à liberdade de expressão: a necessidade da análise de questões políticas, uma vez que tal forma de restrição está sempre permeada por elementos políticos sensíveis e a ausência de elementos probatórios contundentes e objetivos que comprovem tais restrições que, na maior parte das vezes, ocorre em um contexto de legalidade estatal, não sendo tão visíveis e óbvias como outros tipos de restrições.

Finalmente, é importante destacar que a análise dos fatos do caso foi baseada unicamente na sentença da Corte e nos acontecimentos considerados provados pela mesma, uma vez que não houve uma pesquisa primária sobre a questão. 


\section{Capítulo 1 - 0 Sistema Interamericano de Proteção dos Direitos Humanos e sua atuação na proteção da liberdade de expressão}

No contexto atual vivenciado pela América Latina, o Sistema Interamericano de proteção dos direitos humanos desempenha um papel fundamental na proteção da liberdade de expressão. Esse sistema regional foi desenvolvido a partir da metade do século XX no âmbito da OEA e ingressou, a partir da redemocratização vivenciada pelos países latinoamericanos, em uma etapa de fortalecimento e aperfeiçoamento ${ }^{14}$. Serão abordados, nesse capítulo, o âmbito normativo e o âmbito de atuação dos órgãos do Sistema Interamericano em matéria de liberdade de expressão.

\section{1 Âmbito normativo do Sistema Interamericano na proteção da liberdade de expressão}

Em matéria de liberdade de expressão, o Sistema Interamericano pode ser considerado o sistema internacional de maior alcance e com mais amplas previsões de garantias à liberdade de expressão e pensamento ${ }^{15}$.

Com efeito, a Declaração Americana ${ }^{16}$, em seu artigo $\mathrm{IV}^{17}$; a Carta Democrática Interamericana $^{18}$, em seu artigo $4^{\text {o }}{ }^{19}$; a Convenção Americana sobre Direitos Humanos (CADH), em seu artigo 13; e a Declaração de

\footnotetext{
14 TRINDADE, Antônio A. Tratado de direito Internacional dos Direitos Humanos. Vol. III. $1^{\text {aed. }}$ Porto Alegre: Sergio Antonio Fabris Editor, 2003. 59 p.

${ }^{15}$ Informe de La Relatoria Especial para La Libertad de Expresión, 2009. In: Informe Anual de La Comisión Interamericana de Derechos Humanos 2009. OEA/Ser.L/V/II. Doc. 51. 30 de dezembro de 2009. 223 p.

${ }_{16}$ Aprovada na IX Conferência Internacional Americana, realizada em Bogotá, em abril de 1948.

${ }^{17} \mathrm{O}$ artigo IV da Declaração Americana dos Direitos e Deveres do Homem determina que: "Toda pessoa tem o direito à liberdade de investigação, de opinião e de expressão e difusão do pensamento, por qualquer meio."

18 Aprovada pela Assembléia Geral da OEA, na quarta sessão plenária, realizada em 05 de setembro de 2001.

19 O artigo 4 da Carta Democrática Interamericana determina que: "São componentes fundamentais do exercício da democracia a transparência das atividades governamentais, a probidade, a responsabilidade dos governos na gestão pública, o respeito dos direitos sociais e a liberdade de expressão e de imprensa. A subordinação constitucional de todas as instituições do Estado à autoridade civil legalmente constituída e o respeito ao Estado de Direito por todas as instituições e setores da sociedade são igualmente fundamentais para a democracia."
} 
Princípios sobre Liberdade de Expressão ${ }^{20}$ formam o conjunto normativo do sistema na proteção da liberdade de expressão, tendo como objetivo garantir amplamente tal direito, reduzindo, ao mínimo possível, as restrições à livre circulação de informações, opiniões e idéias ${ }^{21}$.

Adotando uma perspectiva comparada entre o artigo 13 da CADH e as disposições relevantes de outros tratados, como o artigo 10 da Convenção Européia de Direitos Humanos e o artigo 19 do Pacto Internacional de Direitos Civis e Políticos (PIDCP), é possível observar que a CADH é a mais ampla ${ }^{22}$, contendo uma lista mais reduzida de restrições à liberdade de expressão. O artigo 10 da Conve nção Européia e o artigo 19 do PIDCP prevêem, respectivamente que:

"Artigo 10:

1. Qualquer pessoa tem direito à liberdade de expressão. Este direito compreende a liberdade de opinião e a liberdade de receber ou de transmitir informações ou ideias sem que possa haver ingerência de quaisquer autoridades públicas e sem considerações de fronteiras. O presente artigo não impede que os Estados submetam as empresas de radiodifusão, de cinematografia ou de televisão a um regime de autorização prévia.

2. O exercício desta liberdades, porquanto implica deveres e responsabilidades, pode ser submetido a certas formalidades, condições, restrições ou sanções, previstas pela lei, que constituam providências necessárias, numa sociedade democrática, para a segurança nacional, a integridade territorial ou a segurança pública, a defesa da ordem e a prevenção do crime, a protecção da saúde ou da moral, a proteção da honra ou dos direitos de outrem, para impedir a divulgação de informações confidenciais, ou para garantir a autoridade e a imparcialidade do poder judicial'.

"Artigo 19:

1. Ninguém poderá ser molestado por suas opiniões.

2. Toda pessoa terá direito à liberdade de expressão; esse direito incluirá a liberdade de procurar, receber e difundir informações e idéias de qualquer natureza, independentemente de considerações de fronteiras, verbalmente ou por escrito, em Oforma impressa ou artística, ou qualquer outro meio de sua escolha.

\footnotetext{
${ }^{20}$ Essa declaração foi formulada pela Comissão Interamericana no ano de 2000.

${ }^{21}$ CORTE IDH. La Colegiación Obligatoria de Periodistas (arts. 13 y 29 Convención Americana sobre Derechos Humanos). Opinión Consultiva OC-5/85 de 13 de novembro de 1985, par. 50. CIDH. Informe Anual 1994. Capítulo V: Informe sobre la Compatibilidad entre las Leyes de Desacato y la Convención Americana sobre Derechos Humanos. Título III. 17 de fevereiro de 1995; Informe Anual 2009. Informe de La Relatoria Especial para Liberdade de Expressão. Capítulo III: Marco Jurídico Interamericano Del derecho a La libertad de expresión, pag. 224.

22 FELGUERAS. Santiago. El derecho a La libertad de expresión e información em La jurisprudência internacional. In: La plicación de los tratados sobre derechos humanos por los tribunales locales. $1^{\mathrm{a}}$ ed. Buenos Aires: Editores Del Puerto, 2004. Pág. 473.
} 
3. O exercício do direito previsto no $\S 2^{\circ}$ do presente artigo implicará deveres e responsabilidades especiais. Conseqüentemente, poderá estar sujeito a certas restrições, que devem, entretanto, ser expressamente previstas em lei e que se façam necessárias para:

a) assegurar o respeito dos direitos e da reputação das demais pessoas;

b) proteger a segurança nacional, a ordem, a saúde ou a moral pública."

Já ao analisarmos o artigo 13 da CADH é possível notar que, comparativamente, apresenta maior proteção à liberdade de expressão, sendo a CADH a única a prever expressamente, em seu texto, a proibição à censura prévia e a vedação a restrições à liberdade de expressão por vias ou meios indiretos ${ }^{23}$.

"Art. 13 - Liberdade de pensamento e de expressão

1. Toda pessoa tem o direito à liberdade de pensamento e de expressão. Esse direito inclui a liberdade de procurar, receber e difundir informações e idéias de qualquer natureza, sem considerações de fronteiras, verbalmente ou por escrito, ou em forma impressa ou artística ou por qualquer meio de sua escolha.

2. O exercício do direito previsto no inciso precedente não pode estar sujeito à censura prévia, mas as responsabilidades ulteriores, que devem ser expressamente previstas em lei e que se façam necessárias para assegurar:

a) o respeito dos direitos e da reputação das demais pessoas;

b) a proteção da segurança nacional, da ordem pública ou da saúde ou da moral públicas.

3. Não se pode restringir o direito de expressão por vias e meios indiretos, tais como o abuso de controles oficiais ou particulares de papel de imprensa, de frequiências radioelétricas ou de equipamentos e aparelhos usados na difusão de informação, nem por quaisquer outros meios destinados a obstar a comunicação e a circulação de idéias e opiniões.

4. A lei pode submeter os espetáculos públicos à censura prévia, com o objetivo exclusivo de regular o acesso a eles, para proteção moral da infância e da adolescência, sem prejuízo do disposto no inciso 2.

5. A lei deve proibir toda propaganda a favor da guerra, bem como toda apologia ao ódio nacional, racial ou religioso que constitua incitamento à discriminação, à hostilidade, ao crime ou à violência."

Por isso, em face da maior preponderância do direito à liberdade de expressão, assegurada pela CADH em comparação aos demais instrumentos internacionais, torna-se imperativo o cuidado que se deve ter ao se analisar a jurisprudência e as normas de outros sistemas para que essas nunca sejam

\footnotetext{
${ }^{23}$ CORTE IDH. La colegiación obligatória de Perioditas. Opinião Consultiva OC5/85 de 13 de novembro de 1985, par. 45. RAMÍREZ, Sérgio G.; GONZA, Alejandra. La libertad de expresión em La jurisprudência de La Corte Interamericana de derechos humanos. $1^{\mathrm{a}}$ ed. San José: Corte Interamericana de Derechos Humanos, 2007, 21p
} 
interpretadas como uma limitação à liberdade de expressão que vá além do que estabelece a $\mathrm{CADH}^{24}$. Esse enfoque baseia-se na norma de interpretação mais favorável, prevista no artigo 29 (b) da $\mathrm{CADH}$, segunda a qual "se em uma mesma situação é aplicável a Convenção Americana e outro tratado internacional, deve prevalecer a norma mais favorável a pessoa humana" 25 .

\section{2 Âmbito de atuação dos órgãos do Sistema hteramericano em matéria de liberdade de expressão}

Atualmente, o Sistema Interamericano baseia-se na atuação de dois órgãos: a Comissão Interamericana de Direitos Humanos e a Corte Interamericana de Direitos Humanos.

\subsubsection{Comissão Interamericana de Direitos Humanos}

A Comissão Interamericana ${ }^{26}$, criada em 1959, foi o primeiro organismo efetivo de proteção de direitos humanos no âmbito do Sistema Interamericano. Com sede em Washington, é considerada um órgão autônomo, cujo mandato surge com a Carta da $\mathrm{OEA}^{27}$ e se consolida, posteriormente, com a Convenção Americana sobre Direitos Humanos $(\mathrm{CADH})^{28}$, aprovada em $1969^{29}$. Conforme estabelece o artigo $1^{\circ}$ de seu

\footnotetext{
${ }^{24}$ Informe de La Relatoria Especial para La Libertad de Expresión, 2004. Capítulo III.A, par. 5, pag.

${ }^{25}$ CORTE IDH. La colegiación obligatória de Perioditas. Opinião Consultiva OC5/85 de 13 de novembro de 1985.

${ }^{26}$ A Comissão Interamericana de Direitos Humanos foi criada na Quinta Reunião de Consulta de ministros de relações Exteriores realizada em Santiago do Chile em agosto de 1959.

${ }^{27}$ A Carta da OEA foi aprovada em 30 de Abril de 1948 em Bogotá e entrou em vigor em 13 de dezembro de 1951. A mesma foi objeto de quatro reformas introduzidas pelo Protocolo de Buenos Aires, aprovado em 27 de Fevereiro de 1967 que entrou em vigor em 27 de Fevereiro de 1970; pelo Protocolo de Cartagena das Índias, aprovado em 5 de dezembro de 1985 que entrou em vigor em 16 de novembro de 1988; pelo Protocolo de Washington, aprovado em 14 de dezembro de 1992 que entrou em vigor em 25 de setembro de 1997; e pelo Protocolo de Manágua, aprovado em 6 de outubro de 1993, que entrou em vigor em 29 de janeiro de 1996.

${ }^{28}$ A Convenção Americana sobre Direitos Humanos foi aprovada em 22 de novembro de 1969 pela Conferencia Especializada Interamericana sobre Direitos Humanos, realizada em San José da Costa Rica, razão pela qual é também conhecida como Pacto de San José da Costa Rica. Entrou em vigor somente em 18 de julho de 1978 e hoje conta com a ratificação de 25 Estados Partes.
} 
Estatuto $^{30}$, "a Comissão Interamericana de Direitos Humanos é um órgão da Organização dos Estados Americanos criado para promover a observância e a defesa dos direitos humanos e servir como órgão consultivo da Organização nessa matéria".

Dentre as atribuições da Comissão, estabelecidas em seu Estatuto, em seu Regulamento ${ }^{31}$ e na CADH, estão o estímulo da consciência dos direitos humanos no continente americano; a análise de casos individuais, os quais, após uma revisão preliminar, podem ser submetidos à Corte; a formulação de recomendações aos Estados; a adoção de medidas cautelares $^{32}$; a produção de relatórios e estudos; e a realização de visitas aos países.

Com a entrada em vigor do Novo Regulamento da Corte Interamericana ${ }^{33} \mathrm{em}^{\circ}$ de janeiro de 2010 , foram introduzidas mudanças quanto ao papel desempenhado pela Comissão no Sistema Interamericano, com o objetivo de fortalecer sua função de órgão do sistema, minimizando sua atuação como parte perante a Corte Interamericana em casos contenciosos. Nesse sentido, foi outorgado maior protagonismo aos Representantes das Vítimas (doravante Representantes) e aos Estados demandados, buscando maior equilíbrio entra as partes durante um litígio. Embora ainda caiba à Comissão iniciar o procedimento perante a Corte, a partir de tal reforma, ela apenas apresenta um relatório do mérito do caso, conforme estabelecido no artigo 50 da $\mathrm{CADH}$, e não mais a demanda, que passa a ser de competência das Vítimas, através de seus Representantes ${ }^{34}$.

\footnotetext{
${ }^{29}$ O que é a CIDH. Disponível em http://www.cidh.oas.org/que.port.htm Acesso em: 16.04.10

${ }^{30}$ Aprovado pela Resolução AG/RES. 447 (IX-o/79), adotada pela Assembléia Geral da OEA em seu Nono Período Ordinário de Sessões, realizado em La Paz, Bolívia, em outubro de 1979;

${ }^{31}$ Aprovado pela Comissão em seu $137^{\circ}$ período ordinário de sessões, realizado de 28 de outubro a 13 de Novembro de 2009. Entrou em vigor em 31 de dezembro de 2009.

32 Consistem em um procedimento de ação urgente previsto pelo Regulamento da Comissão em seu artigo 25 que tem por objetivo prevenir danos irreparáveis às pessoas que se encontrem em uma situação de gravidade ou urgência.

33 Aprovado pela Corte em seu LXXXV Período Ordinário de Sessões celebrado de 16 a 28 de Novembro de 2009. Entrou em vigor em 1 de janeiro de 2010.

34 Corte IDH. Exposición de Motivos de La Reforma Reglamentária. Disponível em: http://www.corteidh.or.cr/reglamento.cfm Acesso em: 17.04.10
} 
No que se refere especificamente à liberdade de expressão, a Comissão já tratou desse tema através da análise de petições individuais ${ }^{35}$, através da adoção de medidas cautelares ${ }^{36}$ e por meio de relatórios sobre países $^{37}$ e sobre temas específicos ${ }^{38}$.

\section{a) Relatoria Especial para Liberdade de Expressão}

Como parte dos seus trabalhos de promoção e defesa dos direitos humanos, a Comissão tem competência para estabelecer relatorias temáticas sobre assuntos específicos de direitos humanos ${ }^{39}$. Em 1997, em consonância com as recomendações feitas por diversos setores da sociedade dos Estados membros da OEA e diante das constantes violações à liberdade de expressão, a Comissão decidiu pela criação da Relatoria Especial para a Liberdade de Expressão ${ }^{40}$. Tal iniciativa encontrou pleno respaldo nos Estados membros da OEA que, na Declaração de Santiago, adotada em abril de 1998, se manifestaram no sentido de que:

"Coincidimos en que una prensa libre desempeña un papel fundamental [para la defensa de los derechos humanos] y reafirmamos la importancia de garantizar la libertad de expresión, de información y de opinión. Celebramos la reciente

\footnotetext{
${ }^{35}$ CIDH. Informe Anual de La Comisión Interamericana de Derechos Humanos 2001. Informe $\mathrm{n}^{\mathrm{o}}$ 128/01, Caso 12.367. Mauricio Herrera Ulloa y Fernán Vargas Rohrmoser Del Diário de "La Nación" (Costa Rica). 3 de dezembro de 2001; Informe Anual de La Comisión Interamericana de Derechos Humanos 2004. Informe $\mathrm{n}^{\circ}$ 5/04. Eduardo Kimel (Argentina). 24 de fevereiro de 2004.

36 A Comissão outorgou medidas cautelares para proteger a liberdade de expressão dos trabalhadores da emissora de televisão Globovisión, localizada na Venezuela. Ver, Informe Anual de La Comisión interamericana de Derechos Humanos 2004. Medidas cautelares outorgadas pela CIDH durante o ano de 2003.

${ }^{37}$ Ver, Relatório sobre a Situação dos Direitos Humanos no México, OEA/Ser.L/V/II.100 Doc.7 rev. 1, 24 de setembro de 1998 e Relatório sobre a Situação dos Direitos Humanos em Colômbia, OEA/Ser.L/II. 102 Doc.9 rev.1, 26 de fevereiro de 1996.

${ }^{38}$ CIDH. Relatório Anual 1994, Relatório sobre a Compatibilidade entre as Leis de Desacato e a Convenção Americana sobre Direitos Humanos, OEA/ser L/V/II.88, Doc. 9 Rev (1995)

39 Ver artigo 41 da Convenção Americana sobre Direitos Humanos e artigo 15.1 do Estatuto da Comissão. ALVAREZ. Ignácio J. Introdução ao Sistema Interamericano de Promoção e Proteção dos Direitos Humanos. In: I Colóqio Internacional de Direitos Humanos: São Paulo, Brasil, 2002. $8 \mathrm{p}$.

${ }^{40}$ A Relatoria foi criada pela Comissão Interamericana durante seu $97^{\circ}$ período de sessões, por decisão unânime de seus membros.
} 
constitución de un Relator Especial para La Libertad de Expresión, en el marco de la Organización de los Estados Americanos" $"$.

A Relatoria Especial para Liberdade de Expressão é considerada um escritório de caráter permanente, que atua dentro do marco jurídico da Comissão, mas com independência funcional e orçamento próprio ${ }^{42}$. Seu modelo de funcionamento é diferente de todas as demais relatorias temáticas, uma vez o Relator para a Liberdade de Expressão não é, ao mesmo tempo, membro da Comissão ${ }^{43}$, o que lhe outorga maior autonomia e independência durante sua atuação.

Foi criada para estimular a consciência e o pleno respeito à liberdade de expressão, considerando o papel fundamental que esse direito desempenha na consolidação do desenvolvimento do sistema democrático $^{44}$. Tem como função proteger e promover a liberdade de expressão e de pensamento no continente americano, através da assessoria prestada à Comissão em relação a $\operatorname{casos}^{45}$, analisando as petições individuais ou solicitações de medidas cautelares ${ }^{46}$; da formulação de recomendações aos Estados; da realização de visitas in loco; e da elaboração de relatórios anuais e estudos especiais temáticos sobre liberdade de expressão ${ }^{47}$. Nota-se que a Relatoria elabora todos os anos um

\footnotetext{
${ }^{41}$ Declaración de Santiago. Segunda Cumbre de las Américas, 18-19 de abril de 1998, Santiago, Chile. In: Documentos Oficiales del Proceso de Cumbres de Miami a Santiago. Volumen I. Oficina de Seguimiento de Cumbres, OEA

42 Conteúdo disponível em: http://www.cidh.org/Relatoria/showarticle.asp?artID=52\&lID=2 Acessado em: 16.04 .10

${ }^{43}$ BERTONI. Eduardo, A. La libertad de expresión em El Estado de derecho. Doctrina y jurisprudência nacional, extramjera e internacional. $2^{\mathrm{a}}$ ed. Buenos Aires: Del Puerto, 2007; XV p.

${ }^{44}$ CANTÓN, Santiago. La Relatoria Especial para La Liberdatad de expresión de La Comisión Interamericana de Derechos Humanos. In.: Instituto Interamericano de Derechos Humanos, Estúdios Básicos de derechos Humanos X. San José, Costa Rica: IIDH, 2000, 71p.

${ }^{45}$ A Relatoria asses sorou a Comissão em casos como: "A Última Tentação de Cristo" vs. Chile; Ivcher Bronstein vs. Peru; Herrera Ulloa vs. Costa Rica, Ricardo Canese vs. Paraguai, Palamara Iribarne vs. Chile, Claude Reyes e outros vs. Chile, Kimel vs. Argentina, Tristan Donoso vs. Panamá, Ríos e outros vs. Venezuela, Perozo e outros vs. Venezuela, Usón Ramirez vs. Venezuela.

${ }^{46}$ A Relatoria assessorou a Comissão em matéria de medidas cautelares em casos como Herrera Ulloa vs. Costa Rica; López Ulacio vs. Venezuela Tristan Donoso vs. Panamá.. No ano de 2009, a Relatoria participou da análise de 35 medidas cautelares a favor de jornalistas, cenógrafos e repórteres no contexto do golpe de Estado ocorrido em Honduras

${ }^{47}$ Informe de La Relatoria Especial para La Libertad de Expresión, 2009. In: Informe Anual de La Comisión Interamericana de Derechos Humanos 2009. OEA/Ser.L/V/II. Doc. 51. 30 de dezembro de 2009. 8 p.
} 
informe sobre a situação da liberdade de expressão nos países do hemisfério e, nos casos em que haja uma especial preocupação quanto à liberdade de expressão em determinado Estado, são realizadas análises com maior profundidade. Esses informes devem ser aprovados pela Comissão para que sejam incluídos nos informes anuais da Comissão ${ }^{48}$.

No entanto, cabe ressaltar que os relatórios elaborados pela Relatoria não tem efeito vinculante para a Corte Interamericana que pode, ao julgar determinado caso, decidir de maneira contrária ao entendimento desenvolvido pela Relatoria ${ }^{49}$. Ademais, embora os Estados membros também não sejam obrigados a seguirem as recomendações realizadas pela Relatoria, a Assembléia Geral da OEA, em diversas resoluções, como em sua Resolução 2523 (XXXIX- 0/09), ressaltou a importância desses instrumentos e convidou os Estados a considerarem tais recomendações na execução e avaliação de suas normas e políticas públicas em matéria de liberdade de expressão, o que demonstra a importância da atuação desse órgão no âmbito do Sistema Interamericano.

No presente trabalho, os relatórios e as recomendações elaborados pela Relatoria Especial serão utilizados como fonte interpretativa do direito à liberdade de expressão, assim como faz a Corte em algumas de suas decisões ${ }^{50}$, e servirão, ainda, como instrumento de contextualização da garantia desse direito em toda a América Latina.

\footnotetext{
${ }^{48}$ CANTÓN, Santiago. La Relatoria Especial para La Liberdatad de expresión de La Comisión Interamericana de Derechos Humanos. In.: Instituto Interamericano de Derechos Humanos, Estúdios Básicos de derechos Humanos X. San José, Costa Rica: IIDH, 2000, 71p.

${ }^{49}$ No caso Kimel vs. Argentina e Usón Ramirez vs. Venezuela, a Corte Interamericana afirmou que é legítima e idônea a utilização da via penal para proteger a liberdade de expressão. No entanto, a Relatoria Especial, reiteradamente defendeu, em seus relatórios, como no relatório de 2009, a descriminalização dos delitos contra a honra.

${ }^{50}$ Ver, CORTE IDH. Caso Rios e outros vs. Venezuela. Sentença de 28 de janeiro de 2009, par. 134.; Caso Perozo e outros vs. Venezuela. Sentença de 28 de Janeiro de 2009, par. 134.
} 


\subsubsection{Corte Interamericana de Direitos Humanos}

A Corte Interamericana, órgão jurisdicional do Sistema Interamericano, com sede na Costa Rica, foi criada pela CADH em 1969, mas começou a funcionar dez anos depois, em 1979, após a entrada em vigor do referido tratado em $1978^{51}$. É uma instituição autônoma da OEA cujo objetivo é a aplicação e interpretação da CADH e outros tratados concernentes ao mesmo assunto ${ }^{52}$. Conforme disposto no artigo $1^{\circ}$ de seu Estatuto, suas funções são regidas pela CADH e pelo seu Regulamento.

A Corte exerce duas competências distintas: a contenciosa e a consultiva.

\section{a) Competência Contenciosa}

Regida pelos artigos 61, 62 e 63 da CADH, a competência contenciosa refere-se à análise e decisão pela Corte Interamericana de medidas provisórias ${ }^{53}$ e de casos concretos, relativos a violações à $\mathrm{CADH}^{54}$ cometidas por determinado Estado parte, submetidos ao seu conhecimento pela Comissão ou por qualquer Estado parte ${ }^{55}$. Ressalta-se que essa competência só é exercida em relação a Estados que tenham aceitado

\footnotetext{
${ }^{51}$ A primeira reunião da Corte Interamericana foi celebrada nos dia 29 e 30 de Junho de 1979 na sede da OEA em Washington, D.C. Em 10 de Setembro de 1981, o Governo da Costa Rica e a Corte Interamericana formaram um Convênio de sede, através do qual a Corte passou a ter sua sede estabelecida na Costa Rica.

${ }^{52}$ Conteúdo disponível em http://www.corteidh.or.cr/index.cfm. Acesso em: 16.04.10

${ }^{53} \mathrm{O}$ artigo 63 da CADH determina que em casos de extrema gravidade e urgência, e quando se fizer necessário evitar danos irreparáveis às pessoas, a Corte, nos assuntos de que estiver conhecendo, poderá tomar as medidas provisórias que considerar pertinente. Se se tratar de assuntos que ainda não estiverem submetidos ao seu conhecimento, poderá atuar a pedido da Comissão.

${ }^{54}$ A Corte só pode exercer sua competência contenciosa em relação à $\mathrm{CADH}$, aos artigos $8^{\circ}$ e 13 do Pacto de San Salvador, à Convenção Interamericana para prevenir e sancionar a tortura; e à Convenção Interamericana sobre desaparecimento forçado de pessoas. Os demais instrumentos só poderão estar sujeitos a competência consultiva da Corte.

55 Somente a Comissão e os Estados-partes podem submeter um caso à Corte Interamericana, não estando prevista a legitimação do indivíduo nos termos do artigo 61 da CADH
} 
expressamente a jurisdição contenciosa da $\operatorname{Corte}^{56}$, nos termos do artigo 62

da $\mathrm{CADH}$, uma vez que se trata de uma cláusula facultativa.

$\mathrm{O}$ autor Antônio Cançado Trindade, ao tratar da competência contenciosa da Corte, estabeleceu que essa não pode substituir os tribunais nacionais dos Estados, atuando como um tribunal de apelação ou uma quarta instância:

"os Tribunais internacionais de direitos humanos existentes- as Cortes Européia e a Interamericana de Direitos Humanos- não "substituem" os Tribunais internos, e tampouco operam como tribunais de recursos ou de cassação de decisões dos tribunais internos. Não obstante, os atos internos dos Estados podem vir a ser objeto de exame por parte de órgãos de supervisão internacionais, quando se trata de verificar a sua conformidade com as obrigações internacionais dos Estados em matéria de direitos humanos" $"$.

No exercício de sua competência contenciosa, até o ano de 2009, a Corte julgou onze casos tratando diretamente do direito à liberdade de expressão $^{58}$ e analisou, ainda, pedidos de medidas provisórias ${ }^{59}$ sobre a matéria.

\footnotetext{
${ }^{56}$ ALVAREZ. Ignácio J. Introdução ao Sistema Interamericano de Promoção e Proteção dos Direitos Humanos. In: I Colóqio Internacional de Direitos Humanos: São Paulo, Brasil, 2002. 10p. 57 TRINDADE, Antônio A. A interação entre o direito internacional e o direito interno na proteção dos direitos humanos. Arquivo do Ministério da Justiça, Brasília, v. 46, n. 182, jul/dez. 1993. $33 \mathrm{p}$.

${ }^{58}$ CORTE IDH. "A Última tentação de Cristo" vs. Chile. Sentença de 5 de fevereiro de 2001 ; Ivcher Bronstein vs. Peru. Sentença de 6 de fevereiro de 2001 ; Herrera Ulloa vs. Costa Rica. Sentença de 2 de julho de 2004 ; Ricardo Canese vs. Paraguai. Sentença de 31 de agosto de 2004; Palamara Iribarne vs. Chile. Sentença de 22 de novembro de 2005; Claude Reyes vs. Chile. Sentença de 19 de setembro de 2006; Kimel vs. Argentina. Sentença de 2 de maio de 2008 ; Tristán Donoso vs. Panamá. Sentença de 27 de Janeiro de 2009; Ríos y otros vs. Venezuela. Sentença de 28 de Janeiro de 2009; Perozo e outros vs. Venezuela. Sentença de 28 de janeiro de 2009; Usón Ramírez vs. Venezuela. Sentença de 20 de Novembro de 2009. Esses são os principais casos que tratam do direito à liberdade de expressão resolvidos pela Corte Interamericana até o ano de 2009. Cabe ressaltar que existem outros casos em que o artigo 13 foi objeto de alegações pelas Partes ou foi analisado pela Corte hteramericana. Entretanto, em tais casos, a liberdade de expressão não é o tema central da nálise e, embora possam vir a ser citados ao longo do texto, adquirem menor relevância para esse trabalho.

${ }^{59}$ CORTE IDH. Caso Del Periódico "La Nación" (Costa Rica). Resolução de 6 de dezembro de 2001; Caso Ivcher Bronstein vs. Peru. Resolução de 14 de março de 2001; Caso Luisiana Ríos y outros vs. Venezuela. Resolução de 27 de novembro de 2002; Caso Marta Colomina y Liliaba elásquez (Venezuela). Resolução de 2 de dezembro de 2003; Caso diários "El nacional" y "Así es La Noticia" (Venezuela). Resolução de 6 de julho de 2004.
} 


\section{b) Competência consultiva}

A competência consultiva refere-se à competência da Corte em interpretar a $\mathrm{CADH}$ ou qualquer outro tratado relativo à proteção dos direitos humanos nos Estados americanos ${ }^{60}$. Conforme estabelece o artigo 64 da $\mathrm{CADH}$, qualquer Estado membro da OEA, parte ou não da $\mathrm{CADH}$, pode solicitar pareceres à Corte em matéria de direitos humanos.

As opiniões consultivas da Corte podem ser de três tipos: (i) as destinadas a interpretar a Convenção Americana; (ii) as que tem por fim a interpretação de outros tratados de proteção dos direitos humanos nos Estados Americanos; e (iii) aquelas que analisam a compatibilidade das leis internas dos Estamos membros com a CADH ou outros tratados concernentes a proteção dos direitos humanos nos Estados Americanos ${ }^{61}$.

Cabe ressaltar que essa competência é muito mais ampla do que a que possui, por exemplo, o Tribunal Europeu ou outros organismos internacionais de direitos humanos, pois não se limita à interpretação da $\mathrm{CADH}$, mas pode alcançar também "outros tratados concernentes à proteção dos direitos humanos nos Estados americanos, sem que nenhuma parte ou aspecto do referido instrumento esteja, em principio, excluído do âmbito dessa função assessora" 62 .

O autor Faúndez Ledesma, nesse sentido, destacou a importância da função consultiva para o Sistema Interamericano, uma vez que a mesma busca assegurar a vigência dos direitos humanos, aumentando a receptividade por parte dos Estados que podem, a qualquer tempo, consultar a opinião da Corte $^{63}$.

\footnotetext{
${ }^{60}$ PIOVESAN, Flávia. Direitos Humanos e o Direito Constitucional Internacional. $9^{\text {a }}$ ed. São Paulo: Saraiva, 2008. p. 255.

${ }^{61}$ PIZZOLO, Calogero. Sistema Interamericano: La denuncia ante La Comision Interamericana de Derechos Humanos, El Processo ante La Corte Interamericana de Derechos Humanos, Informes y

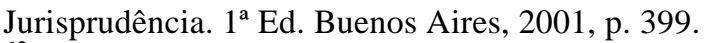

${ }^{62}$ CORTE IDH. Otros Tratados objeto de La Función Consultiva de La Corte (art. 64 Convención Americana sobre Derechos Humanos). Opinião Consultiva OC-1/82 de 24 de setembro de 1982, par. 15 e 16.

${ }_{63}^{6}$ LEDESMA. Hector F. El Sistema Interamericano de Protección de los Derechos Humanos: Aspectos institucionales y procesales. $3^{\text {a }}$ ed. San José: IIDH, 2004. 238p.
} 
No que tange à liberdade de expressão, a função consultiva da Corte é um mecanismo adicional de proteção desse direito ${ }^{64}$, havendo, até o momento, duas opiniões consultivas que tratam diretamente sobre o tema: a opinião consultiva relativa à coligação obrigatória de jornalistas (OC$5 / 85)^{65}$, que será tratada de forma mais aprofundada no capítulo seguinte, e a opinião consultiva referente à exigibilidade do direito de retificação ou resposta (OC-7/86) ${ }^{66}$. Ressalta-se que embora outras opiniões consultivas da Corte Interamericano possam ter impacto indireto no direito à liberdade de expressão, como, por exemplo, a análise da Corte acerca do princípio da igualdade e da não discriminação ${ }^{67}$ ou o desenvolvimento da teoria das limitações permissíveis aos direitos contidos na $\mathrm{CADH}^{68}$, tais instrumentos não serão objeto de análise no presente trabalho.

\footnotetext{
${ }^{64}$ CEJIL. Centro pela Justiça e pelo Direito Internacional. A proteção da liberdade de expressão $e$ o Sistema Interamericano. San José, Costa Rica: Centro por La Justicia y El Derecho Internacional, 2005. $56 \mathrm{p}$.

${ }^{65}$ CORTE IDH. La Colegiación Obligatoria de Periodistas (Arts. 13 e 29 Convención Americana sobre Derechos Humanos). Opinión Consultiva OC-5/85 de 13 de novembro de 1985.

${ }^{66}$ CORTE IDH. Exigibilidade Del Derecho de Rectificación o Respuesta (arts. 14.1, 1.1 e 2 Convención Americana sobre Derechos Humanos). Opinión Consultiva OC-7/86 de 29 de agosto de 1986.

${ }^{67}$ CORTE IDH. Propuesta de Modificación a La Constituición Política de Costa Rica Relacionada com La Naturalización. Opinión Consultiva OC-4/84 de 19 de Janeiro de 1984.

${ }^{68}$ CORTE IDH. La expresión "leyes" em el Artículo 30 de La Convención Americana sobre Derechos Humanos. Opinião Consultiva OC6/86 de 9 de Maio de 1986.
} 


\section{Capítulo 2 - Os padrões estabelecidos pela Jurisprudência da Corte Interamericana de Direitos Humanos em matéria de liberdade de expressão}

\subsection{A importância da Opinião Consultiva- OC 5 para a proteção da liberdade de expressão}

A opinião consultiva $5(\mathrm{OC}-5)^{69}$ consiste no primeiro pronunciamento da Corte acerca do direito à liberdade de expressão no Sistema Interamericano. Nesse parecer, solicitado pelo governo da Costa Rica em 1985, a Corte se pronunciou sobre a interpretação dos artigos 13 e $29^{70}$ da CADH com relação à filiação obrigatória dos jornalistas, disposição exigida em lei interna daquele país, tendo a mesma estabelecido que tal exigência constituía uma violação à liberdade de expressão.

A importância da OC-5, no entanto, reside no fato de que a análise da Corte foi muito mais ampla do que aquela que lhe foi solicitada ${ }^{71}$, pois essa não se limitou a analisar somente a compatibilidade da lei interna do Estado da Costa Rica com a CADH, mas foi além, estabelecendo, pela primeira vez, as bases do direito à liberdade de expressão, determinando importantes padrões de proteção de tal direito. Segundo Eduardo Bertoni, foi através da OC-5 que a Corte construiu os dois pilares básicos para a

\footnotetext{
${ }^{69}$ CORTE IDH. La Colegiación Obligatoria de Periodistas (Arts. 13 e 29 Convención Americana sobre Derechos Humanos). Opinión Consultiva OC-5/85 de 13 de novembro de 1985.

${ }^{70}$ O artigo 29 da CADH determina que: "Nenhuma disposição da presente Convenção pode ser interpretada no sentido de: a) permitir a qualquer dos Estados-partes, grupo ou indivíduo, suprimir o gozo e o exercício dos direitos e liberdades reconhecidos na Convenção ou limitá-los em maior medida do que a prevista nela; b) limitar o gozo e exercício de qualquer direito ou liberdade que possam ser reconhecidos em virtude de leis de qualquer dos estados-partes ou em virtude de Convenções em que seja parte um dos referidos estados; c) excluir outros direitos e garantias que são inerentes ao ser humano ou que decorrem da forma democrática representativa de governo; d) excluir ou limitar o efeito que possam produzir a Declaração Americana dos Direitos e Deveres do Homem e outros atos internacionais da mesma natureza.

71 ADC. Asociación por los derechos Civiles. A liberdade de expressão na jurisprudência da Corte Interamericana de direitos Humanos. Prólogo por Eduardo Bertoni. Pag. 4
} 
interpretação do artigo 13 da CADH, o "padrão democrático" e o "padrão das duas dimensões" ${ }^{72}$.

O primeiro refere-se à ligação estrutural existente entre a democracia e a liberdade de expressão, pois, segundo a Corte, sem a garantia desse direito não há democracia plena, visto que a violação à liberdade de expressão e informação coloca em perigo a vigência de todos os outros direitos e valores democráticos. A Corte expressamente afirma que "a liberdade de expressão se insere na ordem pública primária da democracia que é inconcebível sem o livre debate e sem que a oposição tenha o pleno direito de se manifestar" ${ }^{73}$.

Dessa forma, a liberdade de expressão é considerada um elemento fundamental sobre o qual se baseia a existência de uma sociedade democrática. Nas palavras da Corte, esse direito é a "pedra angular da existência de uma sociedade democrática. (...) É, enfim, condição para que a comunidade, no momento de exercer suas opções, esteja suficientemente informada" 74 .

No que tange ao segundo padrão, "das duas dimensões", a Corte entendeu que a liberdade de expressão tem um alcance e caráter especial. Além de ser considerada um direito individual, através do qual cada cidadão é livre para expressar, por quaisquer meios, suas próprias idéias ou pensamentos; é reconhecida, ainda, como um direito coletivo, por meio do qual toda a sociedade é livre para procurar e receber qualquer informação ou pensamento alheio, contribuindo, a liberdade de expressão, nesse caso, para o intercâmbio de idéias e informações e para a comunicação massiva dos seres humanos ${ }^{75}$.

\footnotetext{
${ }^{72}$ Asociación por los derechos Civiles. A liberdade de expressão na jurisprudência da Corte Interamericana de direitos Humanos. Prólogo por Eduardo Bertoni. Pag. 4

${ }^{73}$ CORTE IDH. La Colegiación Obligatoria de Periodistas (Arts. 13 e 29 Convención Americana sobre Derechos Humanos). Opinión Consultiva OC-5/85 de 13 de novembro de 1985, par. 30 a 32. ${ }^{74}$ CORTE IDH. La Colegiación Obligatoria de Periodistas (Arts. 13 e 29 Convención Americana sobre Derechos Humanos). Opinión Consultiva OC-5/85 de 13 de novembro de 1985, par. 70.

${ }^{75}$ CORTE IDH. La Colegiación Obligatoria de Periodistas (Arts. 13 e 29 Convención Americana sobre Derechos Humanos). Opinión Consultiva OC-5/85 de 13 de novembro de 1985, par. 69. (tradução própria)
} 
Cabe ressaltar que a dimensão individual e a coletiva são indivisíveis, o que significa dizer que, para a garantia plena do direito à liberdade de expressão, é preciso que o Estado respeite de forma simultânea e igual ambas as dimensões. Dessa forma, a Corte entende, por exemplo, que não seria lícito exercer a censura prévia invocando o direito da sociedade de estar bem informada ${ }^{76}$, posto que a lesão de uma das duas dimensões necessariamente terá como contrapartida a lesão da outra. Por isso, para dar efetividade total ao direito à liberdade de expressão, é preciso que se garanta as suas dimensões, individual e coletiva, uma vez que cada uma adquire sentido e plenitude em função da outra ${ }^{77}$.

Com base nessa análise, é possível concluir que a OC-5 tratou da liberdade de expressão como um direito fundamental, estabelecendo as bases de interpretação de tal direito, utilizadas, posteriormente, pela Corte, em diversos casos contenciosos, o que revela sua importância para o Sistema Interamericano.

\subsection{Os elementos do direito à liberdade de expressão na jurisprudência contenciosa da Corte}

Analisando a jurisprudência da Corte Interamericana, é possível extrair três elementos do direito à liberdade de expressão que serão analisados com o objetivo de permitir uma melhor compreensão dos parâmetros estabelecidos pela Corte em sua jurisprudência sobre a matéria: a titularidade do direito à liberdade de expressão; os meios pelo qual é exercido; e o seu objeto.

Em primeiro lugar, quanto à titularidade, nos termos do artigo 13 da $\mathrm{CADH}$, a liberdade de expressão é um direito inerente a todas as pessoas,

\footnotetext{
${ }^{76}$ CORTE IDH. La Colegiación Obligatoria de Periodistas (Arts. 13 e 29 Convención Americana sobre Derechos Humanos). Opinión Consultiva OC-5/85 de 13 de novembro de 1985, par. 33.

${ }^{77}$ RAMÍREZ, Sérgio G.; GONZA, Alejandra. La libertad de expresión em La jurisprudência de La Corte Interamericana de derechos humanos. $1^{\text {a }}$ ed. San José: Corte Interamericana de Derechos Humanos, 2007, 17p.
} 
em condições de igualdade e sem discriminação por motivo nenhum ${ }^{78}$. No caso Tristán Donoso vs. Panamá ${ }^{79}$, em que a Corte analisa o direito à liberdade de expressão de um advogado, determinou que a Convenção Americana deve garantir a liberdade de expressão a toda pessoa, independente de qualquer outra consideração, não cabendo restrições em função da profissão ou de determinado grupo de pessoas.

Ademais, no que tange aos meios de exercício da liberdade de expressão, a $\mathrm{CADH}$ é clara ao estabelecer no artigo 13.1 que aquele que se expressa é livre para escolher o meio de difusão da informação. Nesse sentido, a Corte determinou que a liberdade de expressão não se esgota no direito de falar ou escrever, mas abrange também o direito de difundir os pensamentos, idéias e informações por quaisquer meios ${ }^{80}$. A Corte é clara ao determinar que a expressão e a difusão de informações são indivisíveis. Qualquer limitação ao meio de difusão representa diretamente, e na mesma proporção, uma violação à liberdade de expressão ${ }^{81}$. E, por isso, os Estados têm o dever de não restringir a difusão de informações através de proibição ou interferência nos meios escolhidos por quem se comunica ${ }^{82}$.

No caso Herrera Ulloa vs. Costa Rica ${ }^{83}$, em que a Corte analisou o caso de um jornalista condenado pelo delito de difamação pela publicação e fiel reprodução de notícias anteriormente publicadas na imprensa européia acerca de um diplomata costarricense, a mesma determinou, por exemplo, que as expressões escritas ou impressas dos pensamentos, idéias e

\footnotetext{
78 CIDH. Informe Anual 2009. Informe de La Relatoria Especial para Liberdade de Expressão. Capítulo III: Marco Jurídico Interamericano Del derecho a La libertad de expresión, pag. 226

${ }^{79}$ CORTE IDH. Caso Tristan Donoso vs. Panamá. Sentença de 27 de janeiro de 2009, par. 114.

${ }^{80}$ CORTE IDH. Caso Palamara Iribarne vs. Chile. Sentença de 22 de novembro de 2005, par. 73; Caso Ricardo Caenese vs.Paraguai. Sentença de de 31 de Agosto de 2004, par. 78; Caso Ivcher Bronstein vs. Peru. Sentença de 6 de fevereiro de 2001, par. 147.

${ }^{81}$ CORTE IDH. Caso Palamara Iribarne vs. Chile. Sentença de 22 de novembro de 2005, par. 72; Caso Herrera Ulloa vs. Costa Rica. Sentença de 2 de julho de 2004, par. 109; Caso Ricardo Caenese vs.Paraguai. Sentença de de 31 de Agosto de 2004, par. 78; Caso "A Ultima tentação de cristo vs. Chile”. Sentença de 5 de fevereiro de 2001, par. 36. RAMÍREZ, Sérgio G.; GONZA, Alejandra. La libertad de expresión em La jurisprudência de La Corte Interamericana de derechos humanos. $1^{a}$ ed. San José: Corte Interamericana de Derechos Humanos, 2007, 17p.

${ }^{82}$ CORTE IDH. Caso Palamara Iribarne vs. Chile. Sentença de 22 de novembro de 2005, par. 73; Caso Ricardo Caenese vs.Paraguai. Sentença de de 31 de Agosto de 2004, par. 78; Caso Ivcher Bronstein vs. Peru. Sentença de 6 de fevereiro de 2001, par. 147.

${ }^{83}$ CORTE IDH. Caso Herrera Ulloa vs. Costa Rica. Sentença de 2 de julho de 2001.
} 
informações estão protegidas pelo direito à liberdade de expressão, assim como o idioma escolhido por aquele que se expressa ${ }^{84}$.

Já no caso Palamara Iribarne vs. Chile ${ }^{85}$, referente à condenação do Sr. Palamara pelo delito de desobediência e desacato em decorrência da publicação de um livro no qual criticava o serviço de inteligência chileno e a posterior proibição de publicação e confisco dos exemplares pelo Estado chileno, a Corte entendeu que não bastava que o Estado permitisse que o $\mathrm{Sr}$. Palamara escrevesse suas idéias ou opiniões, mas que, além disso, garantisse à vítima o direito de distribuir o seu livro por qualquer meio capaz de atingir o maior número de destinatários ${ }^{86}$.

Finalmente, no que se refere ao objeto da liberdade de expressão, a princípio, todos os discursos estão protegidos por esse direito, sendo irrelevante sua maior ou menor aceitação estatal ou social. Nesse sentido, a Corte Interamericana determinou, corroborando o entendimento da Corte Européia de Direitos Humanos ${ }^{87}$, que a liberdade de expressão deve ser garantida não somente em relação à difusão de informações ou idéias que são recebidas favoravelmente ou consideradas inofensivas ou indiferentes, mas também a todas as expressões que chocam, inquietam ou ofendem ao Estado ou à fração da população ${ }^{88}$.

A Corte entendeu, ainda, que certos discursos recebem uma proteção especial em função de sua importância para o exercício da democracia: (i) o discurso político e sobre assuntos de interesse público; (ii) o discurso que se refere aos funcionários públicos no exercício de suas funções e sobre candidatos a cargos políticos; e (iii) o discurso que configura um elemento de identidade e dignidade da pessoa que se expressa.

\footnotetext{
${ }^{84}$ CORTE IDH. Caso Herrera Ulloa vs. Costa Rica. Sentença de 2 de julho de 2001, par. 109.

${ }^{85}$ CORTE IDH. Caso Palamara Iribarne vs. Chile. Sentença de 22 de novembro de 2005.

${ }^{86}$ CORTE IDH. Caso Palamara Iribarne vs. Chile. Sentença de 22 de novembro de 2005, par. 73.

${ }^{87}$ CORTE EDH. Caso Handyside vs. Reino Unido. Sentença de 7 de Dezembro de 1976, par. 49; Caso Sunday Times vs. Reino Unido. Sentença de 26 de Abril de 1979, par. 59 e 65; Caso Lingens vs. Áustria. Sentença 8 de Julho de 1986, par. 41.

${ }^{88}$ CORTE IDH. Caso Herrera Ulloa vs. Costa Rica. Sentença de 2 de julho de 2004, par. 113; Caso de "La Última Tentación de Cristo" (Olmedo Bustos y otros) Vs. Chile. Sentença de 5 de fevereiro de 2001, par. 69; Caso Ríos e uotros Vs. Venezuela. Sentença de de 28 de janeiro de 2009, par.105; Caso Perozo y otros Vs. Venezuela. Sentença de 28 de janeiro de 2009, par. 116.
} 
Quanto ao primeiro tipo de discurso, a Corte destacou que a liberdade de expressão corresponde ao direito dos indivíduos e de toda a sociedade de participar dos debates ativos, firmes e desafiantes a respeito dos aspectos vinculados ao funcionamento normal e harmônico da sociedade $^{89}$. Segundo a Corte, em uma sociedade democrática, dada a importância do controle da gestão pública através da opinião, há uma margem muito reduzida a qualquer restrição ao debate político ou questões de interesse público ${ }^{90}$.

Quanto à segunda categoria de discurso, a Corte entende que as expressões, informações e opiniões sobre funcionários públicos no exercício de suas funções e sobre candidatos a cargos políticos gozam de um nível maior de proteção. Essas pessoas, no entendimento da Corte, estão expostas a um maior grau de críticas, uma vez que desempenham funções públicas, de interesse da sociedade e, também porque, além de terem escolhido voluntariamente essa posição, tem uma capacidade maior de contradizerem as informações divulgadas ${ }^{91}$. Nos termos da Corte:

\begin{abstract}
"o controle democrático, por parte da sociedade através das opinião pública, fomenta a transparência das atividades estatais e promove a responsabilidade dos funcionários sobre sua gestão pública, razão pela qual deve se ter em conta uma maior tolerância e abertura a críticas frente a afirmações e apreciações realizadas pelas pessoas no exercício do controle democrático. (...) Ao se permitir o exercício do controle democrático, se fomentas uma maior participação das pessoas nos interesses da sociedade" ${ }^{, 92}$.
\end{abstract}

Um dos casos de suma importância para a proteção da liberdade de expressão no Sistema Interamericano foi o caso Kimel vs. Argentina ${ }^{93}$, em que a Corte analisou a condenação por difamação de um jornalista e escritor

\footnotetext{
${ }^{89}$ CORTE IDH. Caso Ricardo Canese vs. Paraguai.. Sentença de 31 de agosto de 2004, par. 72c.

${ }^{90}$ CORTE IDH. Caso Herrera Ulloa vs. Costa Rica. Sentença de 2 de julho de 2004, par. 127; Caso Ivcher Bronstein vs. Peru. Sentença de 6 de fevereiro de 2001, par. 155.

${ }^{91}$ CORTE IDH. Caso kimel vs. Argentina. Sentença de 2 de maio de 2008, par. 86-88; Caso Ricardo Canese vs. Paraguai. Sentença de 31 de agosto de 2004, par. 83; Caso Claude Reyes e outros vs. Chile. Sentença de 19 de setembro de 2006, par. 87; Caso Tristan Donoso vs. Panamá. Sentença de 27 de janeiro de 2009, par. 115.

${ }^{92}$ CORTE IDH. Caso Herrera Ulloa vs. Costa Rica. Sentença de 2 de julho de 2004, par. 82; Caso Palamara Iribarne vs. Chile. Sentença de 22 de novembro de 2005, par. 83.

${ }^{93}$ CORTE IDH. Caso Kimel vs. Argetina. Sentença de 2 de maior de 2008.
} 
que publicara livro criticando a atuação de um juiz na investigação e julgamento de crimes durante a ditadura militar. A Corte entendeu que o Estado argentino havia violado a liberdade de expressão do Sr. Kimel, na medida em que a crítica realizada pelo jornalista era de notório interesse público, pois se referia à atuação do juiz no exercício de suas funções públicas e não à sua vida pessoal, estando o mesmo, diante de tais circunstâncias, exposto a um maior grau de críticas, o que exige uma ampla tolerância frente às afirmações realizadas, que não podem, assim, ser objeto de sanções ${ }^{94}$.

No caso Palamara Iribarne vs. Chile ${ }^{95}$, anteriormente citado, a Corte examinou a condenação do Sr. Palamara pelo delito de desacato por ter publicado um livro criticando o serviço de inteligência chileno. Entende, a Corte, que o delito de desacato, definido pela Comissão como aquela classe de legislação que penaliza a expressão que ofende, insulta ou ameaça um funcionário público no desempenho de suas funções oficiais ${ }^{96}$, era contrária à $\mathrm{CADH}$.

Um caso mais recente que retrata a maior proteção outorgada aos discursos contra funcionário públicos consiste no caso Usón Ramirez vs. Venezuela $^{97}$, referente à condenação do Sr. Ramirez pelo delito de injúria contra as forças armadas por ter emitido opiniões críticas contra as forças armadas e seus funcionários. A Corte considerou que as afirmações do Sr. Usón estavam especialmente protegidas por referirem-se a entidades e funcionários do Estado sobre os quais recaía um importante debate público $^{98}$.

Por fim, em relação aos discursos que expressam elementos constitutivos da identidade e da dignidade da pessoa, a Corte fez referência à língua dos grupos étnicos ou minorias. No caso López Alvarez vs.

\footnotetext{
${ }^{94}$ CORTE IDH. Caso Kimel vs. Argetina. Sentença de 2 de maior de 2008, par. 87-94.

${ }^{95}$ CORTE IDH. Caso Palamara Iribarne vs. Chile. Sentença de 22 de novembro de 2005.

${ }^{96} \mathrm{CIDH}$. Informe Anual 1994. Capítulo V: Informe sobre a Compatibilidade entre as leis de desacato e a convenção americana de direitos humanos.

${ }^{97}$ CORTE IDH. Caso Usón Ramirez vs. Venezuela. Sentença de 20 de novembro de 2009.

${ }^{98}$ CORTE IDH. Caso Usón Ramirez vs. Venezuela. Sentença de 20 de novembro de 2009, par. 83.
} 
Honduras $^{99}$, a Corte analisou a violação do artigo 13 combinado com o artigo 24 (igualdade perante à lei) da CADH em relação à decisão do diretor de um estabelecimento penal de Honduras que proibira à população garífuna, confinada no local, direito a se comunicar em sua língua de origem. Embora esse caso não seja especialmente destinado à análise da liberdade de expressão, a Corte, em sua sentença, estabeleceu um elemento importante, concluindo que o uso de uma língua própria é essencial para a identidade de uma etnia, na medida em que garante a expressão, difusão e transmissão da cultura, constituindo, ainda, um elemento de diferenciação entre os membros de grupos indígenas da população em geral, garantindo sua identidade cultural própria. Logo, a proibição de utilização de uma língua determinada, atenta contra dignidade pessoal daquele grupo e constitui uma forma grave de discriminação ${ }^{100}$.

Cabe ressaltar que os únicos discursos que não estão protegidos pela liberdade de expressão são aqueles contidos no artigo 13.5 da CADH ou vedados em outros tratados internacionais, quais sejam, (i) a propaganda a favor da guerra e a apologia ao ódio que constitua incitação à violência; (ii) a incitação direta e pública ao genocídio, nos termos da Convenção para Prevenção e Sanção do delito de genocídio; (iii) A pornografia infantil, proibida em termos absolutos pela Convenção sobre os direitos das crianças e o Protocolo Facultativo da Convenção sobre os direitos das crianças. No que tange a essas matérias, a Corte ainda não analisou nenhum caso contencioso.

\subsection{Possibilidade de restrições à liberdade de expressão}

Embora compreendido como um direito fundamental, a liberdade de expressão, no entendimento da Corte, não é um direito absoluto ${ }^{101}$ que pode

\footnotetext{
${ }^{99}$ CORTE IDH. Caso López Alvarez vs. Honduras. Sentença de 1 de fevereiro de 2006.

${ }^{100}$ CORTE IDH. Caso López Alvarez vs. Honduras. Sentença de 1 de fevereiro de 2006, par. 169 174.

${ }^{101}$ CORTE IDH. Caso Kimel vs. Argentina. Sentença de 2 de maio de 2008, par. 54; Caso Palamara Iribarne. Sentença de 22 de novembro de 2005. par. 79; Caso Herrera Ulloa Vs. Costa
} 
ser restringido quando houver um abuso no seu exercício. Isso significa que podem ser impostos limites e controles adequados para o exercício da liberdade de expressão ${ }^{102}$. Destaca-se que o artigo 13 da CADH dispõe expressamente que a liberdade de expressão pode estar sujeita a restrições e determina as condições a que essas restrições devem obedecer, quais sejam: a proibição de censura prévia; os critérios para aplicação das responsabilidades ulteriores; e a proibição de restrições indiretas à liberdade de expressão.

\section{a) Proibição de censura prévia}

Segundo o ex-juiz da Corte Interamericana, Garcia Ramirez, a censura prévia consiste em procedimentos que condicionam a expressão ou difusão de informação sob o controle do Estado, constituindo o meio pelo qual o poder público estabelece controles preventivos para impedir a livre circulação de informações ${ }^{103}$.

Partindo de tal conceito, é importante destacar que, nos termos do artigo 13.2 da $\mathrm{CADH}$, o exercício da liberdade de expressão só pode ser restringido através de responsabilidades ulteriores, não podendo estar sujeito a nenhum tipo de censura prévia, exceto no caso previsto no artigo 13.4 da CADH. Tal dispositivo prevê a possibilidade de lei submeter os espetáculos públicos à censura prévia, com o objetivo exclusivo de regular o acesso a eles, para proteção moral da infância e da adolescência. Exceto nesse caso específico, a Corte, na OC-5, entendeu que a censura prévia é sempre incompatível com o artigo 13 da CADH e que, por isso, nessa

Rica. Sentença de 2 de julho de 2004. par. 120; Caso Tristán Donoso Vs. Panamá. Sentença de 27 de jaaneiro de 2009 par. 110; Caso Ríos y otros Vs. Venezuela. Sentença de 28 de janeiro de 2009. Serie par. 106; Caso Perozo y otros Vs. Venezuela. Sentença de 28 de janeiro de 2009. par. 117.

102 RAMÍREZ, Sérgio G.; GONZA, Alejandra. La libertad de expresión em La jurisprudência de La Corte Interamericana de derechos humanos. $1^{\mathrm{a}}$ ed. San José: Corte Interamericana de Derechos Humanos, 2007, 36p.

${ }^{103}$ RAMÍREZ, Sérgio G.; GONZA, Alejandra. La libertad de expresión em La jurisprudência de La Corte Interamericana de derechos humanos. $1^{\mathrm{a}}$ ed. San José: Corte Interamericana de Derechos Humanos, 2007, 34p. 
matéria, toda medida preventiva significa, inevitavelmente, violação à liberdade de expressão ${ }^{104}$.

A Corte tratou especificamente da censura em dois casos até o momento. No primeiro, "A Última tentação de Cristo vs. Chile” ${ }^{105}$, a Corte entendeu que o Estado chileno violou a liberdade de expressão uma vez que o conselho de qualificação cinematográfica, existente à época em âmbito interno, havia proibido a exibição do filme "A última tentação de Cristo" com base nos pedidos de grupos religiosos que evocavam a proteção da imagem de Jesus Cristo. Um ponto importante dessa decisão foi o entendimento da Corte no sentido de que a censura prévia não emana somente dos poderes executivos e legislativos, mas também do judiciário. A responsabilidade internacional do Estado, nesse sentido, pode surgir por atos ou omissões de qualquer de seus poderes ou órgãos, independente de sua hierarquia, que violem a $\mathrm{CADH}^{106}$.

No caso Palamara Iribarne vs. Chile ${ }^{107}$, segundo caso analisado pela Corte nessa matéria, ficou configurado o exercício da censura prévia pelo Estado, na medida em que foi proibida a publicação do livro "Ética e Serviços de Inteligência", escrito pelo Sr. Palamara; fora ordenada a retirada de circulação de todos os exemplares do livro já existentes; e fora deletada, do computador pessoal do Sr. Palamara, a versão original do seu livro. Esses meios de controle estatais foram considerados pela Corte espécies de censura prévia, incompatíveis com os parâmetros da $\mathrm{CADH}^{108}$.

\footnotetext{
${ }^{104}$ CORTE IDH. La Colegiación Obligatoria de Periodistas (Arts. 13 e 29 Convención Americana sobre Derechos Humanos). Opinión Consultiva OC-5/85 de 13 de novembro de 1985, par. 38. ${ }^{105}$ CORTE IDH. "A Última tentação de Cristo” vs. Chile. Sentença de 5 de fevereiro de 2001.

106 CORTE IDH. “A Última tentação de Cristo” vs. Chile. Sentença de 5 de fevereiro de 2001, par. 53-55.

${ }_{107}$ CORTE IDH. Caso Palamara Iribarne vs. Chile. Sentença de 22 de novembro de 2005.

108 CORTE IDH. Caso Palamara Iribarne vs. Chile. Sentença de 22 de novembro de 2005, par. 78.
} 


\section{b) Dos critérios para aplicação de responsabilidades ulteriores: Teste tripartide}

Considerando que a liberdade de expressão só pode sofrer restrições através de responsabilidades ulteriores e nunca através do exercício da censura prévia, conforme demonstrado anteriormente, a Corte, interpretando o artigo 13 da $\mathrm{CADH}$, estabeleceu um teste tripartide para analisar se determinada restrição à liberdade de expressão pode ser considerada legítima. Esse teste possuiu três critérios principais a serem observados: (i) a restrição deve estar prévia e taxativamente estabelecida em lei; (ii) deve ter um fim legítimo estabelecido no artigo 13.2; e (iii) deve ser necessária em uma sociedade democrática.

\section{b.1) Previsão Legal}

O primeiro critério, imposto pela Corte, determina que as responsabilidades ulteriores devem estar prévia e taxativamente estabelecidas em lei ${ }^{109}$. No caso da restrição à liberdade de expressão ser imposta através do direito penal, a Corte estabeleceu, ainda, que o tipo penal deve conter termos estritos e inequívocos, contendo uma clara definição da conduta incriminada e da sanção a ser imposta, tendo por fim impedir a atuação arbitrária do Estado em estabelecer a responsabilidade penal dos indivíduos ${ }^{110}$. As normas vagas e ambíguas outorgam ao Estado faculdades discricionárias muito amplas, incompatíveis com a liberdade de expressão.

No caso Usón Ramirez vs. Venezuela ${ }^{111}$, a Corte considerou que o delito de "injúria contra as Forças Armadas Nacionais" ${ }^{112}$, pelo qual o Sr.

\footnotetext{
${ }^{109}$ CORTE IDH. Corte I.D.H., Caso Palamara Iribarne vs. Chile. Sentença de 22 de novembro de 2005. par. 79; Caso Herrera Ulloa Vs. Costa Rica. Sentença de 2 de julho de 2004, par. 120; Casoo Tristán Donoso vs. Panamá. Sentença de 27 de janeiro de 2009, par. 117.

110 CORTE IDH. Caso Usón Ramirez vs. Venezuela. Sentença de 20 de novembro de 2009, par. 55; Caso Kimel vs. Argentina. Sentença de 2 de maio de 2008, par. 54; Caso Palamara iribarne vs. Chile. Sentença de 22 de novembro de 2005, par. 63.

${ }^{111}$ CORTE IDH. Caso Usón Ramirez vs. Venezuela. Sentença de 20 de novembro de 2009.
} 
Usón Ramírez havia sido condenado após realizar críticas às Forças Armadas e a seus membros, era tipificado de maneira vaga e ambígua, pois não delimitava claramente qual era a conduta incriminada, o que permitia um campo de atuação arbitrário das autoridades, desrespeitando, assim, as exigências do artigo 13.2 da $\mathrm{CADH}^{113}$.

\section{b.2) Fins previstos no artigo 13.2 da CADH}

O segundo critério impõe que as restrições à liberdade de expressão tenham como objetivo proteger os fins previstos no artigo 13.2 da $\mathrm{CADH}$, quais sejam: (i) os direitos dos demais; (ii) a reputação das demais pessoas; (iii) a segurança nacional; a ordem, a saúde ou a moral públicas. Cabe ressaltar que o Estado não é livre para interpretar esses objetivos de forma a justificar as restrições à liberdade de expressão, devendo levar sempre em conta o entendimento da Corte nessa matéria.

No que tange à proteção dos direitos das demais pessoas, a Corte entende que o exercício dos direitos humanos devem sempre respeitar os demais direitos fundamentais, sendo possível a aplicação, pelos Estados, de responsabilidades ulteriores que busquem um equilíbrio entre os direitos violados e a liberdade de expressão ${ }^{114}$. Mas, cabe ressaltar que, nos casos até agora analisados pela Corte, seu entendimento é claro no sentido de que qualquer restrição à liberdade de expressão que tenha por objetivo proteger outros direitos deve ter como pressuposto a clara lesão ou ameaça a esses direitos, pois, caso contrário, a restrição não é considerada necessária. Isso significa dizer que, dada a importância da liberdade de expressão em uma sociedade democrática, cabe ao Estado demonstrar a real necessidade da restrição da liberdade de expressão em prol de outro direito que se encontre efetivamente ameaçado ou que tenha sido gravemente lesionado, o que

\footnotetext{
${ }^{112}$ Esse delito está previsto no artigo 505 do Código Orgânico da Justiça Militar da Venezuela e dispõe que: "Incorrerá na pena de três a oito anos de prisão aquele que, de alguma forma, injurie, ofenda ou menospreze às Forças Armadas Nacionais ou alguma de suas unidades"

${ }^{113}$ CORTE IDH. Caso Usón Ramirez vs. Venezuela. Sentença de 20 de novembro de 2009, par. 57

${ }^{114}$ CORTE IDH. Caso Kimel vs. Argentina. Sentença de 2 de maio de 2008, par. 75.
} 
impõe, segundo a Corte, a análise de alguns elementos como o dolo daquele que lesionou e as características do dano injustamente causado. ${ }^{115}$

Quanto à proteção da reputação e da honra, a Corte já destacou que a garantia simultânea do direito à honra, previstos no artigo 11 da CADH ${ }^{116}$, e da liberdade de expressão deve ser realizada por meio de uma ponderação casuística, analisando-se as circunstâncias específicas de cada caso concreto $^{117}$. Cabe ressaltar, no entanto, que esse é um ponto de grande relevância e debate no Sistema Interamericano no que tange à descriminalização dos delitos contra a honra.

O entendimento atual da Relatoria e da Comissão Interamericana é o de que a existência de mecanismos penais para a proteção da honra, como os delitos de desacato, difamação, calúnia e injúria, violam, por si só, a liberdade de expressão ${ }^{118}$. Segundo a Comissão Interamericana:

\begin{abstract}
"se se consideram as conseqüências das sanções penais e seu efeito inevitavelmente inibidor que tem sobre a liberdade de expressão, a penalização de qualquer tipo de expressão somente pode ser aplicada em circunstâncias excepcionais em que exista uma ameaça evidente e direta de violência anárquica. (...) As leis que penalizam a expressão de idéias que não incitam à violência anárquica são incompatíveis com a liberdade de expressão e pensamento consagrada no artigo 13 e com o propósito fundamental da Convenção Americana de proteger e garantir a forma pluralista e democrática de vida" ${ }^{119}$.
\end{abstract}

A crítica que se faz à criminalização dos delitos contra a honra consiste no fato de que, em primeiro lugar, essa medida não é necessária, pois existem outros meios menos restritivos, como o direito de retificação ou resposta, consagrado no artigo 14 da CADH e a aplicação de sanções

\footnotetext{
${ }^{115}$ CORTE IDH. Caso Kimel vs. Argentina. Sentença de 2 de maio de 2008, par. 77

${ }^{116} \mathrm{O}$ artigo 11 da CADH dspõe que: 1 . Toda pessoa tem direito ao respeito da sua honra e ao reconhecimento de sua dignidade. 2. Ninguém pode ser objeto de ingerências arbitrárias ou abusivas em sua vida privada, em sua família, em seu domicílio ou em sua correspondência, nem de ofensas ilegais à sua honra ou reputação. 3. Toda pessoa tem direito à proteção da lei contra tais ingerências ou tais ofensas.

${ }^{117}$ CORTE. IDH. Caso Kimel vs. Argentina. Sentença de 2 de maio de 2008, par. 51; Caso Tristan Donoso vs. Panamá. Sentença de 27 de janeiro de 2009, par. 93.

118 CIDH. Relatoria Especial para Liberdade de Espressão. Informe Anual de La Relatoria Especial para La Libertad de Expresión, 2009, Capítulo III, par. 115.

${ }^{119} \mathrm{CIDH}$. Informe Anual 1994. Capítulo V: Informe sobre a Compatibilidade entre as leis de desacato e a Convenção Americana sobre direitos Humanos. Título IV.
} 
civis, conforme destacado pela Relatoria ${ }^{120}$; em segundo lugar, é sempre desproporcional, pois uma condenação penal demonstra ser uma medida além da necessária para a proteção da honra; e, finalmente, constitui um meio indireto de restrição à liberdade de expressão ${ }^{121}$, uma vez que impõe àquele que se expressa a ameaça de prisão ou multa. Conforme destacado pela Comissão, o temor às sanções penais desestimula os cidadãos a expressarem suas opiniões até mesmo sobre problemas de interesse público $^{122}$.

No entanto, ao contrário do entendimento da Relatoria, da Comissão e da maior parte dos doutrinadores, a Corte sustenta que a utilização do direito penal para a proteção da honra é um meio idôneo e legítimo de restrição da liberdade de expressão ${ }^{123}$. Mas, cabe ressaltar que a Corte é clara ao estabelecer que o direito penal é o meio mais restritivo e severo de restrição à liberdade de expressão ${ }^{124}$ e que, por isso, a aplicação das medidas penais deve ser avaliada com especial cautela, devendo ser aplicadas somente em casos de extrema gravidade do abuso da liberdade de expressão. O Estado deve, assim, demonstrar a "absoluta necessidade de utilizar, de forma verdadeiramente excepcional, medidas penais". Caso contrário, violaria o princípio da intervenção mínima e da ultima ratio do direito penal ${ }^{125}$.

É importante destacar que, mesmo a Corte adotando tal entendimento, todos os $\operatorname{casos}^{126}$ concretos em que analisou o conflito entre o direito à liberdade de expressão e o direito à honra, considerou que a

\footnotetext{
${ }^{120}$ CIDH. Relatoria Especial para a liberdade de Expressão. Informe Anual de La Relatoria Especial para La Libertad de Expresión, 2009, Capítulo III, par. 79, 248p.

${ }^{121}$ CEJIL. Centro pela Justiça e pelo Direito Internacional. A proteção da liberdade de expressão e o Sistema Interamericano. San José, Costa Rica: Centro por La Justicia y El Derecho Internacional, 2005. 118p.

${ }^{122} \mathrm{CIDH}$. Informe sobre compatibilidad entre las leyes de Desacato y La Convención Americana sobre Derechos Humanos. In: Informe anual 1994, capítulo V.

${ }^{123}$ CORTE IDH. Caso Ricardo Canese vs. Paraguai. Sentença de 31 de agosto de 2004, par. 104; Caso Kimel vs. Argentina. Sentença de 2 de maio de 2008, par. 71 e 76.

${ }_{124}$ CORTE IDH. Caso Ricardo Canese vs. Paraguai. Sentença de 31 de agosto de 2004, par. 104.

${ }_{125}$ CORTE IDH. Caso Kimel vs. Argentina. Sentença de e de maio de 2008, par. 71, 76 e 78.

${ }^{126}$ CORTE IDH. Caso Herrera Ulloa vs. Costa Rica. Sentença de 2 de julho de 2004; Caso Ricardo Canese vs. Paraguai. Sentença de 31 de agosto de 2004; Caso Kimel vs. Argentina. Sentença de 2 de maio de 2008; Caso Tristan Donoso vs. Panamá. Sentença de 27 de janeiro de 2009; Caso Usón Ramirez vs. Venezuela. Sentença de 20 de novembro de 2009.
} 
aplicação de tipos penais, como difamação, injúria, calúnia ou desacato, era contrária à Convenção Americana por representar sanções desnecessárias e desproporcionais.

Ainda em matéria de proteção do direito à honra, a Corte estabelece alguns requisitos específicos adicionais. Em primeiro lugar, há que se respeitar a doutrina da real malícia ${ }^{127}$, segundo a qual deve ser apurado o conhecimento direto de que a informação difundida era efetivamente falsa (dolo) ou a suspeita de que poderia não ser verdadeira e a atuação negligente do acusado (culpa) ${ }^{128}$. A Corte tratou de tal assunto no caso Tristan Donoso vs. Panamá ${ }^{129}$, no qual o Sr. Donoso foi condenado pelo delito de calúnia por ter acusado o Procurador Geral do país de realizar escutas ilegais de suas conversas, e a Corte entendeu que, mesmo tendo o Procurador sido inocentado das acusações posteriormente, o Sr. Donoso não havia atuado com dolo e, no seu entendimento, a aplicação excepcional de sanções penais deve levar em conta o dolo específico em injuriar, ofender ou menosprezar ${ }^{130}$.

Ademais, segundo a Corte, nos casos em que se pretenda provar a responsabilidade daquele que abusou da liberdade de expressão, o ônus da prova cabe a quem alega o dano. Nesse sentido, no caso Herrera Ulloa vs. Costa Rica, anteriormente citado, no qual o Sr. Herrera Ulloa foi condenado pelo delito de difamação contra um diplomata costarricense, a Corte entendeu que cabe ao Estado provar que as expressões eram falsas e causaram efetivamente o dano alegado. Dessa forma, não se admite que a exceção da verdade, por meio da qual aquele que alega deve provar a veracidade dos fatos, seja interpretada de forma desfavorável àquele que se

\footnotetext{
${ }^{127}$ Esse termo surge na Suprema Corte dos Estados Unidos no caso New York Times vs. Sullivan de 1964.

${ }^{128}$ CEJIL. Centro pela Justiça e pelo Direito Internacional. A proteção da liberdade de expressão e o Sistema Interamericano. San José, Costa Rica: Centro por La Justicia y El Derecho Internacional, 2005. 123p.

${ }^{129}$ CORTE IDH. Caso Tristan Donoso vs. Panamá. Sentença de 27 de janeiro de 2009.

${ }^{130}$ CORTE IDH. Caso Tristan Donoso vs. Panamá. Sentença de 27 de janeiro de 2009, par. 125.
} 
expressou, sob pena de se transformar em uma limitação excessiva à liberdade de expressão ${ }^{131}$.

Finalmente, a Corte determinou que somente questões de fato e não de valor estão suscetíveis a um juízo de veracidade. Isso significa que, quando a informação em análise for um juízo de valor, não poderá ser passível de qualificação como verdadeira ou falsa e que, por isso, o Estado não pode responsabilizar ninguém pela expressão de uma opinião, uma vez que se trata de algo completamente subjetivo ${ }^{132}$.

No que se refere à ordem pública, para que se imponha qualquer restrição à liberdade de expressão com o fim de proteger a ordem pública, entendida como a segurança, a saúde e moral pública, é preciso que esse conceito seja defendido dentro de um critério democrático. A ordem pública, nesse sentido, deve ser entendida como a necessidade de se garantir a existência das condições estruturais para que todas as pessoas, sem discriminação, possam exercer seus direitos livremente. Logo, a ordem pública deve ser interpretada de forma estritamente democrática, não podendo ser invocada para limitar outros direitos. Para a Corte, o conceito de ordem pública impõe que, dentro de uma sociedade democrática, se garantam as maiores possibilidades de circulação de notícias, idéias e opiniões, assim como o mais amplo acesso a informação por toda a sociedade $^{133}$.

\section{b.3) Necessidade em uma sociedade democrática}

O terceiro e último requisito imposto pela Corte, em matéria de responsabilidade ulterior, consiste na verificação de se a restrição à liberdade de expressão é necessária em uma sociedade democrática.

\footnotetext{
${ }^{131}$ CORTE IDH. Caso Herrera Ulloa vs. Costa Rica. Sentença de 2 de julho de 2004, par. 132.

132 CORTE IDH. Caso Kimel vs. Argentina. Sentença de 2 de maio de 2008, par. 93; Caso Tristan Donoso vs. Panamá. Sentença de 27 de janeiro de 2009, par. 124.

${ }^{133}$ CORTE IDH. La Colegiación Obligatoria de Periodistas (Arts. 13 e 29 Convención Americana sobre Derechos Humanos). Opinión Consultiva OC-5/85 de 13 de novembro de 1985, par. 64.
} 
O termo "necessária em uma sociedade democrática", segundo entendimento da Corte Européia incorporado pela Corte Interamericana, significa que não basta que uma sanção seja útil, razoável ou oportuna, é preciso que se configure claramente uma necessidade social certa e imperiosa, um interesse público imperativo que justifique a restrição à liberdade de expressão ${ }^{134}$.

Para ser necessária, a restrição deve, ainda, ser idônea e proporcional ao fim ao qual se destina ${ }^{135}$, ou seja, deve ser uma medida adequada e capaz de proteger as finalidades da $\mathrm{CADH}$, e proporcional ao interesse que a justifica, uma vez que não pode impor uma limitação além do estritamente indispensável para garantir o pleno exercício e alcance da liberdade de expressão $^{136}$.

Ao tratar da proporcionalidade da sanção no caso Kimel vs. Argentina $^{137}$, a Corte estabeleceu critérios de ponderação entre a liberdade de expressão e o direito a ela contraposto. Em primeiro lugar, deve-se avaliar o grau de afetação do outro direito como grave, mediano ou leve; em segundo lugar, observa-se a importância da satisfação do bem contraposto; e, por último, verifica-se se a satisfação desse outro direito justifica a restrição da liberdade de expressão ${ }^{138}$. No caso mencionado, a Corte entendeu que a pena de um ano de prisão mais multa de vinte mil pesos argentinos aplicadas ao Sr. Kimel, referente ao delito de difamação, em decorrência de críticas feitas pelo jornalista a um juiz acerca de sua atuação no julgamento de casos durante a ditadura militar, não era necessária em uma sociedade democrática e era, ainda, notoriamente

\footnotetext{
134 CORTE EDH. Caso The Sunday Times vs. Reino Unido. Sentença de 26 de abril de 1979, par. 35 e 35. CORTE IDH. . La Colegiación Obligatoria de Periodistas (Arts. 13 e 29 Convención Americana sobre Derechos Humanos). Opinión Consultiva OC-5/85 de 13 de novembro de 1985, par. 46; Herrera Ulloa vs. Costa Rica. Sentença de 2 de julho de 2004, par. 122; Ricardo Canese vs. Paraguai. Sentença de 31 de agosto de 2004, par. 96; Caso Palamara Iribarne vs. Chile. Sentença de 22 de novembro de 2005, par. 85.

135 CORTE IDH. Caso Kimel vs. Argentina. Sentença de 2 de maio de 2008, par. 177.

136 CORTE IDH. Caso Kimel vs. Argentina. Sentença de 2 de maio de 2008, par. 83; Caso Palamara Iribarne vs. Chile. Sentença de 22 de novembro de 2005, par. 85; Caso Herrera Ulloa vs. Costa Rica. Sentença de 2 de julho de 2004, par. 123.

${ }^{137}$ CORTE IDH. CasoKimel vs. Argentina. Sentença de 2 de maio de 2008.

${ }^{138}$ CORTE IDH. CasoKimel vs. Argentina. Sentença de 2 de maio de 2008, par. 84.
} 
desproporcional e excessiva, uma vez que o Sr. Kimel estava manifestando uma opinião acerca do desempenho da função do juiz, algo de extrema relevância para o debate social. A Corte afirmou ter havido, assim, o abuso do exercício punitivo do Estado, ficando configurada a manifesta desproporção entre a afetação do direito a honra e da liberdade de expressão, violada pelo Estado ${ }^{139}$.

Diante do exposto, resta claro que qualquer restrição à liberdade de expressão deve estar em conformidade com o artigo 13.2 da CADH e com os requisitos exigidos pela Corte Interamericana, aqui expostos, sob pena de representar uma violação à liberdade de expressão.

\section{c) A proibição de restrições indiretas à liberdade de expressão}

Desde logo, faz-se necessário destacar que os padrões estabelecidos pela Corte em matéria de restrições indiretas à liberdade de expressão constituem tema de suma importância para esse trabalho monográfico, especialmente na análise futura do caso Ríos e outros vs. Venezuela a ser desenvolvida no capítulo 3.

Conforme estabelecido expressamente no artigo 13.3 da $\mathrm{CADH}$, é vedada qualquer restrição à liberdade de expressão por vias ou meios indiretos, tais como o abuso de controles oficiais ou particulares de papel de imprensa, de freqüências radioelétricas ou de equipamentos e aparelhos usados na difusão de informação. Cabe ressaltar que a Corte determinou que esse dispositivo não é taxativo, posto que também é proibida a restrição à liberdade de expressão por quaisquer outros meios indiretos, inclusive aqueles derivados de novas tecnologias ${ }^{140}$.

A Corte também determinou que, para que se configure a restrição ao artigo 13.3 da $\mathrm{CADH}$, é preciso que a via e o meio utilizado restrinja efetivamente, mesmo que de forma indireta, a comunicação e a circulação

\footnotetext{
${ }^{139}$ CORTE IDH. CasoKimel vs. Argentina. Sentença de 2 de maio de 2008, par. 93, 94.

140 CORTE IDH. Caso Ríos e outros vs. Venezuela. Sentença 28 de janeiro de 2009, par. 340; Caso Perozo e outros vs. Venezuela. Sentença de 28 de janeiro de 2009, par. 367.
} 
de idéias e opiniões. Ademais, cabe ressaltar que a responsabilidade do Estado por restrições indiretas engloba não somente a atuação estatal, mas também os controles exercidos por particulares que produzam o mesmo resultado $^{141}$.

Sobre esse tema, a Corte já tratou de diferentes tipos de restrições indiretas. No primeiro caso acerca da matéria, Ivcher Bronstein vs. Peru ${ }^{142}$, o Sr. Bronstein era cidadão naturalizado peruano e proprietário majoritário de um canal de televisão crítico ao governo. Um mês após a exibição de um programa denunciando supostas torturas cometidas por membros do Serviço de Inteligência do Exército, o governo aprovou uma lei que autorizava o cancelamento da nacionalidade de peruanos naturalizados. $\mathrm{O}$ Sr. Ivcher, além de ter sua cidadania cancelada, o que impedia que continuasse como proprietário do meio de comunicação, foi denunciado por difamação contra as forças armadas. Durante esse processo, foi, ainda, alterada a composição e atribuição dos tribunais que atuaram diretamente no litígio em questão. A Corte, diante de tais circunstâncias, entendeu que toda restrição à liberdade de expressão deve ser analisada diante de um contexto à luz dos fatos do caso em sua totalidade ${ }^{143}$. Diante do contexto configurado nesse caso, a Corte concluiu, então, que as ações do Estado constituíram meio indireto de restrição à liberdade de expressão.

Ainda, no caso Palamara Iribarne vs. Chile ${ }^{144}$, a Corte entendeu que a investigação sumária administrativa e a decisão de suspender a autorização que tinha o autor para publicar seu livro, constituíram restrições indiretas à liberdade de expressão e pensamento.

Já no caso Ricardo Canese vs. Paraguai ${ }^{145}$, a Corte, ao analisar a condenação do Sr. Canese, candidado à presidência, por difamar outro

\footnotetext{
${ }^{141}$ CORTE IDH. La Colegiación Obligatoria de Periodistas (Arts. 13 e 29 Convención Americana sobre Derechos Humanos). Opinión Consultiva OC-5/85 de 13 de novembro de 1985, par. 47 e 48; Caso Ríos e outros vs. Venezuela. Sentença 28 de janeiro de 2009, par. 107 a 110 e 340; Caso Perozo e outros vs. Venezuela. Sentença de 28 de janeiro de 2009, par. 118 a 121 e 367.

142 CORTE IDH. Caso Ivcher Bronstein vs. Peru. Sentença de 6 de fevereiro de 2001.

143 CORTE IDH. Caso Ivcher Bronstein vs. Peru. Sentença de 6 de fevereiro de 2001, par. 154.

144 CORTE IDH. Caso Palamara Iribarne vs. Chile. Sentença de 22 de novembro de 2005, par. 94.

${ }^{145}$ CORTE IDH. Caso Ricardo Canese vs. Paraguai. Sentença de 31 de agosto de 2004
} 
candidato, concluiu que o processo penal contra a vítima e a proibição de sair do país por mais de oito anos imposta ao Sr. Canese constituíram meios indiretos de restrição de sua liberdade de expressão ${ }^{146}$.

Finalmente, é preciso destacar que uma restrição à liberdade de expressão pode violar, ao mesmo tempo, o artigo 13.2 e 13.3 da CADH. Dessa forma, uma sanção pode constituir uma restrição direta à liberdade de expressão por ser, por exemplo, ilegítima, desnecessária ou desproporcional e, também, restringir indiretamente tal direito por ter como efeito o silenciamento e a intimidação de futuras expressões, gerando a autocensura na sociedade, que passa a temer ser responsabilizada no futuro por suas expressões $^{147}$.

Esse tipo de restrição indireta apresenta grande relevância para o presente estudo. A autocensura, fenômeno que ocorre quando a sociedade e principalmente aqueles que trabalham e fazem parte dos meios de comunicação condicionam o exercício de seu trabalho informativo ao medo gerado pelas possíveis sanções, pode ser considerada, no contexto atual latino-americano, o pior mal para a comunicação em uma sociedade livre ${ }^{148}$.

A Corte tratou da autocensura no caso Tristán Donoso vs. Panamá $^{149}$, citado anteriormente, em que o Sr. Donoso foi condenado pelo delito de calúnia por ter acusado o Procurador Geral do país de realizar escutas ilegais de suas conversas. Parte da condenação consistira na aplicação de uma sanção civil com caráter reparatório muito elevado o que, segundo a Corte Interamericana, produz um efeito intimidatório e inibitório para o exercício da liberdade de expressão, uma vez que tal sanção tem a capacidade de comprometer a vida pessoal e familiar daquele que denuncia fatos relativos a funcionários públicos, produzindo o resultado perigoso da

\footnotetext{
146 CORTE IDH. Caso Ricardo Canese vs. Paraguai. Sentença de 31 de agosto de 2004, par. 107.

147 Importante destacar que esse tipo de restrição indireta também é chamada pela doutrina americana como "chilling effect". No entanto, esse termo e sua análise não será objeto desse trabalho, pois não é a forma adotada pela Corte Interamericana em suas decisões.

148 AZNAR, Hugo. Comunicación Responsable: La autoregulacion de los médios. $2^{\mathrm{a}}$ Ed. Barcelona: Editorial Ariel, S.A, 2005. 17p.

${ }^{149}$ CORTE IDH. Caso Tristán Donoso Vs. Panamá. Sentença de 27 de janeiro de 2009
} 
autocensura, tanto em relação ao afetado como em relação a todas as demais pessoas na sociedade ${ }^{150}$.

Nessa mesma linha de pensamento, a Comissão Interamericana, em casos submetidos à Corte, destacou o problema da autocensura, afirmando que a abertura de processos penais e civis contra jornalistas e comunicadores sociais, fundamentados na investigação ou publicação de informações de interesse público, viola a liberdade de expressão por desestimular o debate público na sociedade, já que a simples ameaça de um processo penal por expressões críticas ao governo pode gerar a autocensura $^{151}$.

Esse tema será ainda abordado na análise do caso Ríos e outros vs. Venezuela no capítulo 3 desse trabalho, uma vez que, no caso citado, o Estado impõe restrições à liberdade de expressão por meio e vias indiretas, causando a autocensura nos meios de comunicação e na sociedade venezuelana como um todo, conforme restará demonstrado a seguir.

\footnotetext{
${ }^{150}$ CORTE IDH. Caso Tristán Donoso Vs. Panamá. Sentença de 27 de janeiro de 2009, par. 129.

${ }^{151} \mathrm{CIDH}$. Alegações da Comissão Interamericana no caso Herrera Ulloa vs. Costa. In: CORTE IDH. Caso Herrera Ulloa vs. Costa Rica. Sentença de 2 de julho de 2004, par. 101.2; Alegações da Comissão Interamericana no caso Palamara Iribarne vs. Chile. In: CORTE IDH. Caso Palamara Iribarne vs. Chile. Sentença de 22 de novembro de 2005, par. 64,e.
} 


\section{Capítulo 3 - Os desafios impostos pelo Caso Ríos e outros vs. Venezuela}

Após a análise dos padrões estabelecidos pela jurisprudência da Corte Interamericana em matéria de liberdade de expressão, será discutido, nesse capítulo, de forma mais aprofundada, o caso Ríos e outros vs. Venezuela. Tal demanda foi submetida pela Comissão Interamericana à Corte em 26 de outubro de 2006, tendo sido proferida a sentença em 28 de janeiro de 2009.

\subsection{Fatos dos casos}

Os fatos do caso abrangem aproximadamente quarenta episódios ocorridos entre dezembro de 2001 e junho de 2004, período em que a Venezuela passava por conflitos institucionais e políticos, marcados por uma extrema polarização da sociedade. Dentre esses episódios, destaca-se a greve convocada pela Confederação de Trabalhadores da Venezuela e pela Fedecámaras (Federación de Cámaras y Asociaciones de Comercio y Producción de Venezuela) em 9 de abril de 2002 e a realização de uma marcha de oposição ao governo, em 11 de abril do mesmo ano, que exigia a renúncia de Hugo Chávez, Presidente da República. Tais eventos resultaram em atos de violência com grande número de mortos e feridos, numa tentativa fracassada de um golpe militar; e na conseqüente criação de um clima de agressão e ameaça aos jornalistas, operadores de câmeras e fotógrafos e a todos os demais trabalhadores dos meios de comunicação social $^{152}$.

Dentro desse contexto político conturbado, os fatos abordados no caso tratam dos atos e omissões cometidos por funcionários públicos do Estado venezuelano e por particulares que foram caracterizados como restrições ao direito de buscar, receber e difundir informações de vinte

\footnotetext{
${ }^{152}$ CORTE IDH. Caso Ríos e outros vs. Venezuela. Sentença de 28 de janeiro de 2009, par. 46, 47.
} 
pessoas, todas elas jornalistas ou trabalhadores da emissora de televisão $\mathrm{RCTV}^{153}$ (Compañía Anônima Radio Caracas Televisión), meio de comunicação privado mais antigo do país, com maior audiência e linha editorial crítica ao governo ${ }^{154}$. As vítimas do caso foram submetidas a diversas ameaças, atos de intimidação e agressões verbais e físicas por parte do Estado e por particulares.

Para fins desse trabalho, destacamos alguns fatos considerados provados pela Corte Interamericana a fim de contextualizar melhor o caso:

(i) Os senhores Isnardo Bravo, Wilmer Marcano e Winston Gutírrez, vítimas do caso, foram agredidos, em 3 de abril de 2002, por um grupo de pessoas não identificadas que atiraram pedras, baldes de água e urina e os ameaçaram atingir com cadeiras do local em que realizavam uma cobertura jornalística. Tais fatos ficaram comprovados através de filmagens realizadas no momento ${ }^{155}$.

(ii) A Senhora Mavarez, jornalista da RCTV, foi atingida, no dia 10 de abril de 2002, por uma pedra lançada por uma pessoa não identificada, enquanto realizava uma cobertura de notícias na sede de Petróleos de Venezuela (PDVSA), o que resultou em um ferimento grave em seu rosto $^{156}$.

(iii) A Senhora Luisiana Ríos, em 2 de maio de 2002, foi ameaçada por membros e simpatizantes do governo, enquanto cobria uma matéria no parlamento da Venezuela. Tais pessoas encontravam-se ao redor do prédio e realizavam diversas ameaças a jornalista, o que a fez permanecer por mais de três horas no prédio com medo de que pudesse sofrer alguma agressão

\footnotetext{
${ }^{153}$ Rádio Caracas televisión, RCTV é o meio de comunicação privado mais antigo da Venezuela, fundado em 15 de novembro de 1953 por William H. Phelps Jr.

${ }_{154}$ CHIRINOS. Carlos. Caso RCTV: más que um conflicto mediático. Disponível em: http://www.lanacion.cl/prontus_noticias/site/artic/20070525/pags/20070525223058.html. Acesso em: 16.06 .10 .

${ }^{155}$ CORTE IDH. Caso Ríos e outros vs. Venezuela. Sentença de 28 de janeiro de 2009, par. 172.

${ }^{156}$ CORTE IDH. Caso Ríos e outros vs. Venezuela. Sentença de 28 de janeiro de 2009, par. 173 176.
} 
física, razão pela qual precisou do auxílio da polícia metropolitana para deixar o local ${ }^{157}$.

(iv) O Senhor Arnando Amaya, assistente de câmera da RCTV, durante uma filmagem, em 12 de novembro de 2002, foi ferido por um disparo de arma de fogo. A vítima já havia recebido diversas ameaças e afirmou ter sido ferido por partidários pró-governo que atiraram contra ele e outras pessoas ao seu redor ${ }^{158}$.

(v) Os senhores Pérez Hansen, Javier García e Isnardo Bravo, vítimas da demanda e trabalhadores da RCTV, no dia 12 de março de 2003, realizavam uma cobertura jornalística na Universidade Central da Venezuela (UCV), quando foi lançada uma bomba lacrimogênea no local. Ao saírem, foram abordados por uma pessoa que lhes arrancou o microfone e os equipamentos, após os insultar. As vítimas ainda alegaram que um grupo de pessoas identificadas como membros do M-28 ("Tomistas"), movimento de apoio ao governo, os agrediram com pedras, tentaram incendiar os veículos da RCTV enquanto gritavam "Malditos periodistas! Los vamos a matar!" $" 159$. Anteriormente, no dia 15 de agosto de 2002, o Senhor David Pérez Hansen, ao cobrir uma declaração do vice-presidente da República, já havia sido ameaçado de morte e sofrera violência física por parte de simpatizantes do governo ${ }^{160}$.

(vi) A rede RCTV, durante todo o período ao qual o caso se refere, foi objeto de intromissões por parte das autoridades, que a obrigou a seguir diretrizes relativas ao conteúdo dos programas, tendo ainda ocorrido procedimentos administrativos sancionatórios e interrupções dos sinais privados. É preciso citar, como exemplo, o procedimento administrativo iniciado, pela Comissão Nacional de Telecomunicações (CONATEL), em 5 de junho de 2002, logo após as manifestações, no qual alegava uma suposta

\footnotetext{
${ }^{157}$ CORTE IDH. Caso Ríos e outros vs. Venezuela. Sentença de 28 de janeiro de 2009, par. 185189.

${ }^{158}$ CORTE IDH. Caso Ríos e outros vs. Venezuela. Sentença de 28 de janeiro de 2009, par. 217221.

${ }^{159}$ CORTE IDH. Caso Ríos e outros vs. Venezuela. Sentença de 28 de janeiro de 2009, par. 166 168

${ }^{160}$ CORTE IDH. Caso Ríos e outros vs. Venezuela. Sentença de 28 de janeiro de 2009, par. 213.
} 
inadimplência tributária da emissora, além de inúmeras fiscalizações e intervenções realizadas pela CONATEL e pelo Serviço Nacional Integrado de Administração Aduaneira e Tributaria (SENIAT) ${ }^{161}$.

(vii) Foram verificados episódios violentos na sede da emissora nos dias 14 de agosto de 2003 e 3 de junho de 2004, em que grupos de particulares utilizaram-se de meios violentos, como incendiar um caminhão da emissora e escrever insultos em suas paredes, produzindo danos materiais no local, obrigando os funcionários a se retirarem somente com apoio de uma escolta $\operatorname{armada}^{162}$.

A Comissão e os Representantes das Vítimas alegaram que tais episódios violentos contra as vítimas da demanda foram derivados da atuação do Estado e dos discursos proferidos pelas altas autoridades estatais venezuelanas que realizaram de forma reiterada, através dos meios de comunicação de alto alcance, pronunciamentos em que se referiam a RCTV como "jinetes del Apocalipsis", "fascistas", que desenvolviam "una campaña de terrorismo", "que están concertados en una acción contra el gobierno de Venezuela, contra el pueblo, contra las leyes y contra la República". Aqueles que trabalhavam na RCTV foram chamados de "mentirosos, perversos, inmorales, golpistas y terroristas"163. O governo, durante seus discursos, ainda ameaçou fechar a RCTV, cancelando a licença de operação da emissora ${ }^{164}$.

A Comissão também destacou a falta de diligência na investigação de tais incidentes e a omissão do Estado em prevenir tais fatos ${ }^{165}$. Diante dos acontecimentos, a Comissão solicitou à Corte que declarasse o Estado da Venezuela responsável pela violação dos artigos $5^{\circ}$ (direito à integridade pessoal), 13 (direito à liberdade de pensamento e expressão), $8^{\circ}$ (garantias judiciais) e 25 (proteção judicial) da $\mathrm{CADH}$, todos combinados com o

\footnotetext{
${ }^{161}$ CORTE IDH. Caso Ríos e outros vs. Venezuela. Sentença de 28 de janeiro de 2009, par. 33.

${ }^{162}$ CORTE IDH. Caso Ríos e outros vs. Venezuela. Sentença de 28 de janeiro de 2009, par. 130.

${ }^{163}$ CORTE IDH. Caso Ríos e outros vs. Venezuela. Sentença de 28 de janeiro de 2009, par. 115.

${ }^{164}$ CORTE IDH. Caso Ríos e outros vs. Venezuela. Sentença de 28 de janeiro de 2009, par. 336.

${ }^{165}$ CORTE IDH. Caso Ríos e outros vs. Venezuela. Sentença de 28 de janeiro de 2009, par. 2.
} 
artigo 1.1 (obrigação de respeitar os direitos contidos na $\mathrm{CADH}$ ) do mesmo instrumento.

O Estado, por sua vez, sustentou que os meios de comunicação realizaram uma campanha midiática feroz, através da qual se incitava a população à realização de atos contra a ordem e a paz pública. Acusou, ainda, a RCTV de fazer parte do golpe militar que tentou derrubar o Presidente Hugo Chávez do poder ${ }^{166}$. Nesse sentido, a Corte afirmou que analisaria, conforme exige suas funções, somente a responsabilidade internacional do Estado e não a responsabilidade da RCTV, o papel social da emissora ou seu envolvimento em questões políticas. Por isso, mesmo que as vítimas, trabalhadores da RCTV, tivessem praticado atos contrários ao governo, isso não justificaria o descumprimento das obrigações estatais de respeitar e garantir os direitos humanos ${ }^{167}$.

\subsection{0 contexto histórico da Venezuela no momento dos fatos}

Para a análise do caso, é preciso destacar brevemente o contexto histórico e político venezuelano à época dos fatos em questão, mesmo que esse não seja o foco do presente estudo. Em 2 fevereiro de 1999, o Presidente Hugo Chávez assumiu, através de eleições populares, a Presidência da República. Seu governo foi marcado, desde o início, por uma forte polarização política e social. Os sintomas de tal polarização se manifestaram em três momentos importantes: o primeiro refere-se à greve petrolífera ocorrida entre finais de 2002 e início de 2003, quando somente os setores informais da economia não pararam suas atividades; o segundo, à tentativa de golpe de estado realizada em abril de 2002; e o terceiro momento refere-se ao referendo presidencial de 15 de agosto de 2004, no qual Chávez obteve massiva votação a seu favor ${ }^{168}$.

\footnotetext{
${ }^{166}$ CORTE IDH. Caso Ríos e outros vs. Venezuela. Sentença de 28 de janeiro de 2009, par 51. ${ }^{167}$ CORTE IDH. Caso Ríos e outros vs. Venezuela. Sentença de , pqr. 62.

168 VILLA, Rafael D. Venezuela: mudanças políticas na era Chávez. Estudos Avançados. vol.19 no.55 São Paulo Sept./Dec. 2005.
} 
Nota-se que os fatos do caso Ríos e outros vs. Venezuela estão inseridos exatamente nesse contexto de extrema polarização política, cabendo dar destaque para o movimento golpista, realizado em abril de 2002, que destitui, por menos de dois dias, o Presidente Hugo Chávez de seu cargo, culminando na alteração do cenário político venezuelano.

Após tal episódio, houve uma nítida alteração da política venezuelana que, sempre com o pretexto de impedir novos golpes contrários ao governo, vem adotando medidas que constituem restrições a garantias fundamentais, como a liberdade de expressão ${ }^{169}$. Foi, entretanto, nos anos de 2002 e 2003 que se deu, na Venezuela, o ponto mais alto de ataques físicos contra jornalistas e organismos internacionais de direitos humanos ${ }^{170}$, momento em que o governo passou a adotar medidas discriminatórias contra os meios de comunicação opositores ao regime, considerados "conspiradores antidemocráticos e golpistas", independentemente do fato de terem os mesmo relação ou não com o golpe de $2002^{171}$.

\subsection{Uma análise crítica da Sentença da Corte Interamericana de Direitos Humanos}

Inicialmente, destaca-se que, embora a Corte tenha se pronunciado na sentença acerca de todos os artigos alegados pela Comissão, o foco desse trabalho será somente a análise acerca da violação do artigo 13 da CADH.

Ademais, é importante ressaltar que a sentença da Corte não trouxe nenhuma inovação nos padrões que vinha seguindo em sua jurisprudência. Sua relevância consiste em demonstrar, de forma crítica, que, mesmo diante

\footnotetext{
${ }^{169}$ HRW, Human Rights Watch. Uma Década de Chávez.Intolerância política y oportunidades perdidas para El progreso de los derechos humanos em Venezuela. Disponível em: http://www.hrw.org. Acesso em 15.06.10; 1p.

170 BERTONI. Eduardo. La libertad de expresión em Venezuela. Disponível em www.anuariocdh.uchile.cl., 124p.

${ }^{171}$ HRW, Human Rights Watch. Uma Década de Chávez.Intolerância política y oportunidades perdidas para El progreso de los derechos humanos em Venezuela. Disponível em: http://www.hrw.org. Acesso em 15.06.10; 1p.
} 
dos fatos do caso e dos padrões consolidados em matéria de liberdade de expressão, a Corte optou por não aplicá-los, deixando de responsabilizar o Estado venezuelano pelas violações indiretas a esse direito, desconsiderando a autocensura provocada pelas políticas governamentais adotadas pelo Estado.

Dessa forma, a decisão da Corte não foi capaz de superar os desafios e obstáculos impostos pelas formas indiretas de restrição à liberdade de expressão, evidenciadas no caso em estudo. Em primeiro lugar, as restrições indiretas a esse direito estão permeadas, na maior parte dos casos, por questões políticas sensíveis e, ao se manter à margem de tais questões, a Corte não pôde se aprofundar no tema, deixando de se pronunciar acerca de seu efeito intimidador e da autocensura. Além disso, por ser exercida através de meios e vias indiretas, a restrição indireta à liberdade de expressão, muitas vezes, não apresenta elementos probatórios explícitos e objetivos, o que, no caso, resultou na não responsabilização do Estado.

Nota-se que a maior parte dos fatos e argumentos apresentados pela Comissão e pelos Representantes das Vítimas, apontados na seção 1 desse capítulo, não foram considerados violações à liberdade de expressão, por não apresentarem, no entendimento da Corte, elementos suficientes e capazes de caracterizarem uma restrição a esse direito. Quando entendeu haver violação à liberdade de expressão, a Corte somente declarou a responsabilidade do Estado pela violação do artigo 13.1 combinado com 1.1 da $\mathrm{CADH}$, em relação aos pronunciamentos realizados pelos funcionários públicos contrários à RCTV e a seus membros, em razão da omissão do Estado em garantir às vítimas o direito de buscar, receber e difundir informações.

Nesse sentido, a Corte declarou a ausência de violação do artigo 13.3 da CADH que trata das restrições indiretas à liberdade de expressão ${ }^{172}$, optando por deixar de afirmar a existência de meios e vias indiretas de violação desse direito na Venezuela, ignorando, ainda, o efeito intimidador

${ }^{172}$ CORTE IDH. Caso Ríos e outros vs. Venezuela. Sentença de 28 de janeiro de 2009, par. 416. 
e a autocensura, derivadas da conduta Estatal. Foram observados dois obstáculos principais impostos por essa forma de restrição, evidenciados pelo caso, que não puderam ser superados pela Corte: a necessidade da análise de questões políticas para a identificação das restrições indiretas e a ausência de elementos probatórios contundentes e objetivos.

\section{a) Questões políticas sensíveis}

A Comissão Interamericana e os Representantes das Vítimas, ao apresentarem os fatos e seus argumentos, tentaram demonstrar à Corte Interamericana um padrão de conduta ou política do Estado de violação à liberdade de expressão. Afirmaram que as violações haviam se dado em um contexto de extrema polarização política na Venezuela, de forma que todos os fatos estavam permeados por imprescindíveis análises políticas. Frente a tal situação, buscaram provar que as ameaças e lesões causadas à RCTV e às vítimas da demanda foram consequiências diretas e naturais do discurso agressivo e violento do Presidente e das altas autoridades governamentais contra os opositores ao regime ${ }^{173}$.

Os representantes ainda argumentaram que os episódios violentos foram causados por partidários do governo que detêm apoio direto e indireto do Estado para agredir, física e moralmente a emissora, seus jornalistas e trabalhadores da RCTV ${ }^{174}$. Os episódios violentos teriam sido provenientes tanto de grupos organizados, como os Círculos Bolivarianos, quanto de grupos para-estatais como o Movimeno M-28, Movimento Tupamaro, Movimento Carapacia e a Frente Bolivariana de Libertação, financiados de maneira aberta e reconhecida pelo governo venezuelano com recursos do Estado. Tais grupos, conforme alegaram os Representantes, recebem recursos e armas para defender o Presidente, atuando em colaboração com o governo ${ }^{175}$. Cabe ressaltar que a Comissão, alegando

\footnotetext{
173 CORTE IDH. Caso Ríos e outros vs. Venezuela. Sentença de 28 de janeiro de 2009, par. 113.

${ }^{174}$ CORTE IDH. Caso Ríos e outros vs. Venezuela. Sentença de 28 de janeiro de 2009, par 132.

${ }^{175}$ CORTE IDH. Caso Ríos e outros vs. Venezuela. Sentença de 28 de janeiro de 2009, par. 133.
} 
não possuir os elementos probatórios suficientes para comprovar a ligação desses grupos com o governo, apresentou como argumento a responsabilidade internacional do Estado somente por fatos cometidos por particulares de forma genérica, excluindo, o quanto era possível, a análise de toda a questão política por trás da existência desses grupos prógoverno $^{176}$.

A Corte, assim como fez a Comissão, buscou excluir a análise política, alegando que a existência desses grupos e sua relação com o governo estavam fora do marco fático do caso. Por isso, decidiu, a Corte, que não há, na demanda, elementos probatórios suficientes para atribuir a esses grupos o vínculo com os episódios violentos cometidos contra as vítimas $^{177}$.

Ademais, no entendimento da Corte, a realização por parte das altas autoridades venezuelanas de discursos contrários à RCTV não representa, por si só, a existência de uma política de Estado. Para a Corte, não há elementos suficientes que comprovem que o Estado tenha autorizado, instigado, instruído ou ordenado os atos de agressão e violência contra as vítimas do caso $^{178}$.

Dessa forma, o que se quer demonstrar é que as considerações políticas trazidas por esse caso dificultaram e, até mesmo, impediram a análise mais profunda das violações à liberdade de expressão, cometidas pelo Estado venezuelano. A Corte, em muitos momentos, por se colocar à parte do contexto político dos acontecimentos, não foi capaz de analisar se as atitudes e políticas governamentais adotadas pelo Estado violaram a liberdade de expressão das vítimas através de meios e vias indiretos.

\footnotetext{
176 CORTE IDH. Caso Ríos e outros vs. Venezuela. Sentença de 28 de janeiro de 2009, par 133. 177 CORTE IDH. Caso Ríos e outros vs. Venezuela. Sentença de 28 de janeiro de 2009, par. 134. ${ }^{178}$ CORTE IDH. Caso Ríos e outros vs. Venezuela. Sentença de 28 de janeiro de 2009, par 144.
} 


\section{b) Elementos probatórios objetivos e contundentes}

Outro obstáculo não superado pela Corte consiste no fato de que as restrições indiretas não apresentam, em geral, elementos probatórios objetivos que as comprovem. Nota-se que o Estado venezuelano, no caso em questão, atuava em um marco de legalidade, não tendo aplicado qualquer tipo de censura prévia ou restrição direta à liberdade de expressão ilegítima que tornasse mais evidente a violação a esse direito. A perseguição aos jornalistas e aos meios de comunicação, através dos episódios violentos apresentados, não foi, em momento algum, realizada por meio do aparato estatal, mas sim pela violência cometida por particulares que eram apoiados através de um padrão de conduta estatal e da política governamental.

Tais circunstâncias revelam a necessidade da Corte de realizar uma análise ainda mais aprofundada dos casos quando se tratar de uma restrição indireta à liberdade de expressão, devendo a mesma levar sempre em consideração o contexto no qual as restrições foram praticadas, conforme havia determinado no caso Ivcher Bronstein vs. Peru ${ }^{179}$. A Corte por não ter examinado as restrições à liberdade de expressão diante do contexto e à luz dos fatos do caso em sua totalidade, declarou a ausência de responsabilidade do Estado pela violação do artigo 13.3 da CADH.

Para fins desse trabalho, é preciso destacar os elementos apontados pela Comissão e pelos Representantes como caracterizadores da violação indireta à liberdade de expressão, cometida por meio das políticas públicas do Estado: (i) os pronunciamentos dos altos funcionários públicos do Estado contrários à RCTV e a todos os seus trabalhadores e membros, incluindo ameaças de fechamento da emissora; (ii) as ingerências em sua programação e (iii) a interrupção do sinal de transmissão da RCTV.

Dentre essas questões, a única que a Corte entendeu ter havido violação à liberdade de expressão foi aquela referente aos pronunciamentos

${ }^{179}$ CORTE IDH. Caso Ivcher Bronstein vs. Peru. Sentença de 6 de fevereiro de 2001. 
dos funcionários públicos e do próprio Presidente da República, contrários à emissora RCTV e a seus membros. Mesmo assim, considerou que o Estado violara o artigo 13.1 da CADH combinado com 1.1 (obrigação de respeitar os direitos contidos na $\mathrm{CADH}$ ) da mesma, diante do descumprimento de sua obrigação de garantir o exercício da liberdade de buscar, receber e difundir informação, não tendo a Corte se pronunciado sobre a violação do artigo 13.3 da $\mathrm{CADH}$, o que demonstra sua dificuldade em identificar e declarar a existência de violações indiretas à liberdade de expressão.

Não obstante tenha a Corte se omitido e negado a existência de restrições indiretas à liberdade de expressão, faz-se relevante a análise de sua decisão acerca dos pronunciamentos dos funcionários públicos contrários à RCTV, por evidenciar a opção adotada pela Corte de não declarar expressamente que o Estado venezuelano violara a liberdade de expressão por vias e meios indiretos através das atuações e políticas governamentais. A Corte optou por responsabilizar o Estado, a nosso entendimento, de forma mais branda, pela violação do artigo 13.1 por não ter garantido às vítimas o direito de buscar, receber e difundir informações.

Consta nos fatos do caso que foram realizados pronunciamentos de altos funcionários do Estado em meio ao contexto de polarização política, através dos quais faziam referência à RCTV como "jinetes del Apocalipsis", "fascistas", que "tienen una campaña de terrorismo", "que están concertados en una acción contra el gobierno de Venezuela, contra el pueblo, contra las leyes y contra la República", "mentirosos, perversos, inmorales, golpistas y terroristas" ${ }^{180}$. A Comissão argumentou que esse tipo de pronunciamento criara um ambiente de forte intolerância e fanatismo que poderia resultar em atos de violência contra as pessoas identificadas como trabalhadores da RCTV, impedindo o livre exercício de suas funções periodistas ${ }^{181}$.

\footnotetext{
${ }^{180}$ CORTE IDH. Caso Ríos e outros vs. Venezuela. Sentença de 28 de janeiro de 2009, par. 115.

${ }^{181}$ CORTE IDH. Caso Ríos e outros vs. Venezuela. Sentença de 28 de janeiro de 2009, par. 116.
} 
Ao analisar a questão, a Corte Interamericana entendeu que os pronunciamentos dos funcionários públicos tinham caráter oficial, uma vez que eram realizados através dos meios de comunicação proporcionados pelo Estado $^{182}$. Ainda no entendimento da Corte, os pronunciamentos de funcionários públicos devem ser feito com maior diligência do que aqueles realizados por particulares em razão de sua alta investidura, do amplo alcance e dos eventuais efeitos que suas expressões podem ter sobre a população; e em razão de possuírem uma posição de garantes dos direitos humanos. Dessa forma, a Corte declarou que os funcionários públicos tem um dever de especial cuidado que se vê acentuado diante de situações de maior conflito na sociedade, alterações da ordem pública ou polarização social ou política, especialmente porque, nesse contexto específico, suas declarações podem representar um grave riscos a determinadas pessoas ou $\operatorname{grupos}^{183}$.

Entretanto, mesmo diante de todo o contexto de violações reiteradas à liberdade de expressão, a Corte afirmou que as declarações dos funcionários públicos não poderiam ser consideradas uma política do Estado de violação a esse direito ou constituírem, em si mesmas, autorização, instigação ou promoção dos atos de violência perpetrados contra as vítimas. Declarou somente que os pronunciamentos contrários à RCTV colocaram seus trabalhadores e membros em uma posição de maior vulnerabilidade frente ao Estado e determinados setores da sociedade. ${ }^{184}$ Nesse sentido, a Corte concluiu que tais declarações são incompatíveis com a obrigação estatal de garantir a todos a liberdade de buscar, receber e difundir informações ${ }^{185}$, obrigação essa disposta no artigo 13.1 combinado com 1.1 da $\mathrm{CADH}$, mas ignorou que tais discursos constituem meios

\footnotetext{
${ }^{182}$ CORTE IDH. Caso Ríos e outros vs. Venezuela. Sentença de 28 de janeiro de 2009, par 138.

${ }^{183}$ CORTE IDH. Caso Ríos e outros vs. Venezuela. Sentença de 28 de janeiro de 2009, par 139.

${ }^{184}$ CORTE IDH. Caso Ríos e outros vs. Venezuela. Sentença de 28 de janeiro de 2009, par 145, 146.

${ }^{185}$ CORTE IDH. Caso Ríos e outros vs. Venezuela. Sentença de 28 de janeiro de 2009, par 145, 149.
} 
indiretos de restrição à liberdade de expressão que impõe graves danos à população diante de seu efeito intimidador.

É preciso ressaltar que a Corte, quando analisou as ameaças de fechamento da emissora RCTV, realizadas pelo governo em seus discursos, mencionou, de forma rápida e superficial, que poderiam povocar efeito intimidador e a autocensura, mas, novamente, optou por não declarar a violação do artigo 13.3 da $\mathrm{CADH}$, mas tão-somente do artigo 13.1 da mesma. A Corte preferiu não se aprofundar no tema da autocensura, elementos que, embora permeie o caso em sua totalidade, é ignorado na sentença $^{186}$.

As demais questões suscitadas pela Comissão e pelos Representantes das Vítimas, relativas às ingerências e interrupções da transmissão do sinal da emissora, conforme destacado, não foram consideradas pela Corte uma violação à liberdade de expressão.

No que se refere à ingerência na programação da emissora, a Comissão alegou que a CONATEL enviou diversos ofícios à rede RCTV com o objetivo de regular a sua programação. Por exemplo, foi enviado ofício à emissora, após as manifestações, afirmando que um de seus programas ("La entrevista em El observador”) havia transgredido uma norma legal vigente (artigo 6 do Regulamento Parcial sobre transmissões de Televisão) por mostrar cenas com alto conteúdo de violência, exigindo a alteração do horário do programa. O que a Comissão buscou demonstrar à Corte foi que o objetivo dos ofícios enviados à emissora era pressionar de forma indireta a direção da RCTV a fim de alterar o conteúdo das informações difundidas pelo meio de comunicação. Entretanto, a Corte entendeu não haver elementos que evidenciassem a restrição indireta da liberdade de expressão das vítimas.

Ainda, acerca das ingerências realizadas na emissora, a Comissão destacou que a RCTV foi obrigada a permitir a transmissão de diversas intervenções por parte de funcionários públicos, entes estatais e

\footnotetext{
${ }^{186}$ CORTE IDH. Caso Ríos e outros vs. Venezuela. Sentença de 28 de janeiro de 2009, par. 341.
} 
organizações públicas que utilizaram-se do canal para realizar pronunciamentos nos dias 8 e 9 de abril de 2002. Além disso, alegou, a Comissão, que no dia 13 de abril de 2002, um grupo de soldados foi à sede da emissora e obrigou o fechamento do canal para que o Estado pudesse realizar suas transmissões através do sinal utilizado pela RCTV ${ }^{187}$. A Corte entendeu que a transmissão de pronunciamentos públicos está amparado pela lei venezuelana, não havendo elementos suficientes para se determinar se o número de mensagens transmitidas constituíram uso legítimo ou arbitrário dessa faculdade estatal e que a interrupção do sinal da emissora não configurava ato concreto de violação indireta da liberdade de expressão $^{188}$.

Por conseguinte, o que se pôde observar, através da exposição desse obstáculo, foi a dificuldade encontrada pela Corte Interamericana de aplicar os padrões estabelecidos em matéria de liberdade de expressão e declarar a responsabilidade do Estado pelas violações indiretas à liberdade de expressão diante da ausência de elementos probatórios considerados explícitos e objetivos. É preciso ressaltar que por serem realizadas através de meios indiretos, as formas de violação indireta à liberdade de expressão raramente possuem elementos objetivos que as comprovem, necessitando de uma análise mais profunda e que leve em consideração o contexto no qual estão inseridas, o que não foi realizado pela Corte no caso em questão.

\subsection{Especificidades do caso}

Notadamente, o caso não traz nenhuma inovação nos padrões desenvolvidos pela Corte Interamericana em sua jurisprudência em matéria de liberdade de expressão. Entretanto, é um caso que, conforme exposto, impôs enormes desafios à Corte, uma vez que a violação à liberdade de

\footnotetext{
${ }^{187}$ CORTE IDH. Caso Ríos e outros vs. Venezuela. Sentença de 28 de janeiro de 2009, par 145, 362.

${ }^{188}$ CORTE IDH. Caso Ríos e outros vs. Venezuela. Sentença de 28 de janeiro de 2009, par 145, 373.
} 
expressão ocorreu em um contexto de extrema polarização política, por meio indiretos de restrição a esse direito.

Todas as ameaças e violações da liberdade de expressão verificadas no caso só podem ser compreendidas quando analisadas em conjunto e diante do contexto político que o permeia. Cabe ressaltar que, a princípio, quando analisamos os fatos de maneira isolada, não há responsabilidade a ser imputada ao Estado, visto que este não violou qualquer lei interna ou agiu diretamente de forma contrária à liberdade de expressão. A dificuldade do caso está exatamente na ausência de elementos fáticos certos e explícitos de uma violação flagrante à liberdade de expressão.

As violações ocorreram sempre de forma indireta e não tão evidente. Entretanto, isso não significa uma menor lesão ao direito à liberdade de expressão. Ao contrário, demonstra uma forma menos visível e, podemos dizer, mais eficaz de violação à liberdade de expressão, através da qual o Estado, atuando no marco de legalidade em aparente conformidade com a $\mathrm{CADH}$, realiza atos e adota políticas públicas que indiretamente impedem a existência de um ambiente propício e idôneo para o exercício da liberdade de expressão, causando uma espécie de intimidação e autocensura camuflada. Como conseqüência, a sociedade venezuelana e principalmente os meios de comunicação, diante dos atos de violência, ameaças contra os comunicadores e as ingerências e sanções aplicadas a esses meios, passam a se sentir amedrontados e intimidados a expressarem suas opiniões e críticas.

Conforme destacado no capítulo 2 desse estudo, a autocensura pode ser considerada o pior mal para a comunicação em uma sociedade livre ${ }^{189}$. Segundo o autor Garmán Bidart Campos, esse é um fenômeno muito mais difícil de se regular normativamente do que outras restrições à liberdade de expressão, porque se produz espontaneamente sem que, na maioria dos casos, seja possível detectar um autor responsável a quem aplicar-lhes pessoalmente um dever de atuar. Isso porque consiste, esse fenômeno, no

189 AZNAR, Hugo. Comunicación Responsable: La autoregulacion de los médios. $2^{\mathrm{a}}$ Ed. Barcelona: Editorial Ariel, S.A, 2005. 17p. 
fato das pessoas preferirem guardar silêncio, dissimular sua opinião, calar uma crítica, deixando de expor um ponto de vista com medo do resultado que aquilo pode lhe causar. Muitas vezes, essa é uma questão patológica na sociedade, no qual o principal responsável pode ser o Estado ao impedir ou não estimular a criação de uma ambiente propício à livre difusão de informações ${ }^{190}$.

$\mathrm{O}$ autor Eduardo Bertoni também se manifestou nesse sentido, ao afirmar que a percepção da autocensura em uma sociedade é um processo lento que não ocorre de um dia para o outro, o que requer uma investigação prolongada para se analisar se um determinado ambiente é ou não idôneo para o exercício da liberdade de expressão ${ }^{191}$.

Dessa forma, resta claro que, diante das especificidades do caso, a Corte não foi capaz de identificar e responsabilizar o Estado pelo exercício da autocensura, por meios e via indiretos de restrição à liberdade de expressão que impediram o pleno exercício da liberdade de expressão na sociedade venezuelana.

\footnotetext{
${ }^{190}$ CAMPOS, Germán B. A auto-censura na liberdade de expressão. In: Revista El Derecho, Buenos Aires, To. 83, 895p.

191 BERTONI. Eduardo. La libertad de expresión em Venezuela. Disponível em www.anuariocdh.uchile.cl. 125p.
} 


\section{Conclusão}

Conforme se pretendeu demonstrar ao longo do trabalho, o processo de fortalecimento da democracia na América Latina, vivenciado a partir dos anos 90, elevou a liberdade de expressão à posição de um direito fundamental e requisito sine qua non da democracia, tendo se consolidado como um direito constitucionalmente protegido na ordem jurídica dos países latino-americanos.

No entanto, as ameaças e violações a esse direito não cessaram, o que representa um obstáculo a ser ainda enfrentado pelo Sistema Interamericano. O que requer, entretanto, uma especial atenção, é o fato de que surgem, no contexto latino-americano atual, formas menos visíveis e óbvias de restrição à liberdade de expressão como aquelas observadas em momento histórico anterior. O exercício da censura prévia, a aplicação de sanções desproporcionais, a prisão de jornalistas e o desaparecimento forçado de pessoas contrárias ao governo, embora não tenham desaparecido integralmente, dão espaço a novas formas de violações à liberdade de expressão por meio de políticas públicas que visam causar a intimidação e a autocensura na sociedade.

A autocensura, por não ser evidente e por ser um fenômeno muito difícil de se normatizar, impõe sérias dificuldades à Corte Interamericana na análise de casos concretos, uma vez que, em geral, os elementos probatórios são baseados em análises políticas que não são capazes de comprovar objetivamente a existência desse tipo de restrição.

Podemos dizer que se trata de um processo misto, no sentido de que, em um primeiro momento, a causa da autocensura é externa, normalmente oriunda da atuação dos Estados que impedem ou não garantem o exercício pleno da liberdade de expressão; mas, em momento posterior, transforma-se em um elemento interno a cada indivíduo que, condicionado pelo medo e pela intimidação, opta por se manter em silêncio, deixando de expressar 
uma opinião ou crítica. Diante da internalização da autocensura na sociedade, surge a dificuldade de identificá-la e reprimi-la.

Tais circunstâncias puderam ser percebidas através da análise do caso Ríos e outros vs. Venezuela que demonstrou a existência de formas indiretas de restrição à liberdade de expressão, perpetuadas pelo Estado através de sua atuação e de políticas governamentais que geraram, na população e nos meios de comunicação, um efeito intimidatório e a autocensura.

Ressalta-se que o Estado atuou, a todo tempo, dentro de um marco de legalidade, dificultando ainda mais a percepções dos objetivos que estavam por trás de suas atitudes. A Corte, portanto, não foi capaz de identificar esses elementos e responsabilizar o Estado de forma expressa pela utilização de vias e meios indiretos de restrição à liberdade de expressão. Optou por se manter à margem das questões plíticas e, por diversas vezes, afirmou não haver elementos fáticos e contundentes de que os fatos apresentados tivessem representado alguma violação à liberdade de expressão.

Dessa forma, o que se pode concluir é que ainda existem, no contexto latino-americano atual, obstáculos a serem enfrentados pela Corte Interamericana na proteção da liberdade de expressão, especialmente em matéria de restrições indiretas a esse direito. Por envolver questões políticas sensíveis e não apresentar elementos probatórios objetivos e contundentes, as restrições indiretas apresentam-se como violações menos visível e explícitas à liberdade de expressão, impondo-se como um importante desafio para o Sistema Interamericano. 


\section{Referências Bibliográficas}

ALVAREZ. Ignácio J. Introdução ao Sistema Interamericano de Promoção e Proteção dos Direitos Humanos. In: I Colóquio Internacional de Direitos Humanos: São Paulo, Brasil, 2002.

AZNAR, Hugo. Comunicación Responsable: La autoregulacion de los médios. $2^{\mathrm{a}}$ Ed. Barcelona: Editorial Ariel, S.A, 2005.

BERTONI. Eduardo, A. La libertad de expresión en El Estado de derecho. Doctrina y jurisprudência nacional, extranjera e internacional. $2^{\mathrm{a}}$ ed. Buenos Aires: Del Puerto, 2007.

CAMPOS, Germán B. A auto-censura na liberdade de expressão. In: Revista El Derecho, Buenos Aires, To. 83.

CANTÓN, Santiago. La Relatoria Especial para La Libertad de expresión de La Comisión Interamericana de Derechos Humanos. In.: Instituto Interamericano de Derechos Humanos, Estúdios Básicos de derechos Humanos X. San José, Costa Rica: IIDH, 2000.

CEJIL. Centro pela Justiça e pelo Direito Internacional. A proteção da liberdade de expressão e o Sistema Interamericano. San José, Costa Rica: Centro por La Justicia y El Derecho Internacional, 2005.

FELGUERAS. Santiago. El derecho a La libertad de expresión e información en la jurisprudência internacional. In: La plicación de los tratados sobre derechos humanos por los tribunales locales. $1^{\mathrm{a}}$ ed. Buenos Aires: Editores Del Puerto, 2004. 
LEDESMA. Hector F. El Sistema Interamericano de Protección de los Derechos Humanos: Aspectos institucionales y procesales. $3^{\mathrm{a}}$ ed. San José: IIDH, 2004.

LEGLER, Thomas F.; LEAN, Sharon F.; BONIFACE, Dexter S. Promoting democracy in the Americas. $1^{\mathrm{a}}$ ed. Maryland: The Johns Hokins University Press, 2007.

PIOVESAN, Flávia. Direitos Humanos e o Direito Constitucional Internacional. $9^{\mathrm{a}}$ ed. São Paulo: Saraiva, 2008.

PIZZOLO, Calogero. Sistema Interamericano: La denuncia ante La Comision Interamericana de Derechos Humanos, el Processo ante La Corte Interamericana de Derechos Humanos, Informes y Jurisprudência. $1^{\mathrm{a}}$ Ed. Buenos Aires, 2001.

RAMÍREZ, Sérgio G.; GONZA, Alejandra. La libertad de expresión em La jurisprudência de La Corte Interamericana de derechos humanos. $1^{\mathrm{a}} \mathrm{ed}$. San José: Corte Interamericana de Derechos Humanos, 2007.

TRINDADE, Antônio A. Tratado de direito Internacional dos Direitos Humanos. Vol. III. 1ªd. Porto Alegre: Sergio Antonio Fabris Editor, 2003. A interação entre o direito internacional e o direito interno na proteção dos direitos humanos. Arquivo do Ministério da Justiça, Brasília, v. 46, n. 182, jul/dez. 1993.

VILLA, Rafael D. Venezuela: mudanças políticas na era Chávez. Estudos Avançados. vol.19 no.55 São Paulo Sept./Dec. 2005. 


\section{Documentos Eletrônicos}

ADC, Asociación por los derechos Civiles. A liberdade de expressão na jurisprudência da Corte Interamericana de direitos Humanos. Disponível em:

http://www.adcsidh.org/images/files/documento_estandares_libex_final_ult imoport.pdf. Acesso em: 15.04.10.

BANCO MUNDIAL. La voz de los pobres. Hay alguien que nos escuche? de Deepa Narayan, 2000. Disponível em: http://siteresources.worldbank.org/INTPOVERTY/Resources/3356421124115102975/1555199-1124115187705/vol1_sp.pdf. Acesso em: 10.05.10.

BERTONI. Eduardo. La libertad de expresión en Venezuela. Disponível em www.anuariocdh.uchile.cl. Acesso em 19.06.10.

COMISSÃO INTERAMERICANA DE DIREITOS HUMANOS. $O$ que é $a$ $C I D H$. Disponível em http://www.cidh.oas.org/que.port.htm. Acesso em: 16.04.10.

CORTE IDH. Exposición de Motivos de La Reforma Reglamentária. Disponível em: http://www.corteidh.or.cr/reglamento.cfm. Acesso em: 17.04.10.

_____ Información hisorica. Disponível em: http://www.corteidh.or.cr/index.cfm. Acesso em: 16.04.10.

HRW, Human Rights Watch. Uma Década de Chávez.Intolerância política y oportunidades perdidas para El progreso de los derechos humanos em Venezuela. Disponível em: http://www.hrw.org. Acesso em 15.06.10. 
RELATORIA ESPECIAL PARA LIIBERDADE DE EXPRESSÃO. http://www.cidh.org/Relatoria/showarticle.asp?artID=52\&IID=2. Acesso em: 16.04.10.

\section{Jurisprudência}

\section{Corte Interamericana de Direitos Humanos}

CORTE INTERAMERICANA DE DIREITOS HUMANOS. Otros Tratados objeto de La Función Consultiva de La Corte (art. 64 Convención Americana sobre Derechos Humanos). Opinião Consultiva OC-1/82 de 24 de setembro de 1982 .

. . Propuesta de Modificación a La Constituición Política de Costa Rica Relacionada com La Naturalización. Opinión Consultiva OC-4/84 de 19 de Janeiro de 1984.

. La Colegiación Obligatoria de Periodistas (arts. 13 y 29 Convención Americana sobre Derechos Humanos). Opinión Consultiva OC-5/85 de 13 de novembro de 1985.

. Opinião Consultiva OC-6/86, La Expresión "Leyes" em el artículo 30 de La Convención Americana sobre Derechos Humanos", de 09 de Maio de 1986.

Exigibilidade Del Derecho de Rectificación o Respuesta (arts. 14.1, 1.1 e 2 Convención Americana sobre Derechos Humanos). Opinión Consultiva OC-7/86 de 29 de agosto de 1986. 
. La Última Tentación de Cristo vs. Chile. Sentença de 5 de fevereiro de 2001.

. Ivcher Bronstein vs. Peru. Sentença de 6 de fevereiro de 2001.

. Herrera Ulloa vs. Costa Rica. Sentença de 2 de julho de 2004.

. Ricardo Canese vs. Paraguai. Sentença de 31 de agosto de 2004.

___ Palamara Iribarne vs. Chile. Sentença de 22 de novembro de 2005.

. López Alvarez vs. Honduras. Sentença de 1 de fevereiro de 2006.

. Claude Reyes y otros vs. Chile. Sentença de 19 de setembro de 2006.

. Kimel vs. Argentina. Sentença de 02 de maio de 2008.

. Tristán Donoso vs. Panamá. Sentença de 27 de Janeiro de 2009.

. Ríos y otros vs. Venezuela. Sentença de 28 de Janeiro de 2009.

. Perozo e outros vs. Venezuela. Sentença de 28 de janeiro de 2009.

. Usón Ramírez vs. Venezuela. Sentença de 20 de Novembro de 2009. 


\section{Corte Européia de Direitos Humanos}

CORTE EUROPÉIA DE DIREITOS HUMANOS. Handyside vs. Reino Unido. Sentença de 7 de Dezembro de 1976.

. Sunday Times vs. Reino Unido. Sentença de 26 de abril de 1979.

Lingens vs. Áustria. Sentença 8 de Julho de 1986.

\section{Relatórios}

COMISSÃO INTERAMERICANA DE DIREITOS HUMANOS. Informe sobre La compatibilidad de lãs leyes de desacato y La Convención Americana sobre Derechos Humanos, Informe Anual de 1994.

. Informe Anual de La Relatoria Especial para La Libertad de Expresión, 2002.

_____. Informe Anual de La Relatoria Especial para La Libertad de Expresión, 2004.

. Estudo Especial sobre el derecho de acceso a la información, 2007.

. Democracia y Derechos Humanos em Venezuela, 2009.

Informe Anual de La Relatoria Especial para La Libertad de Expresión, 2009. 